\title{
Market Segmentation in Urban Tourism: Exploring the Influence of Personal Factors on Tourists' Perception
}

\author{
Amina Chebli \\ Ecole Polytechnique d'Architecture et Urbanisme d'Alger. EPAU. Algiers Algeria \\ Laboratoire Ville, Urbanisme et Développement Durable, VUDD \\ Meriem Chabou Othmani \\ Ecole Polytechnique d'Architecture et Urbanisme d'Alger. EPAU. Algiers Algeria \\ Foued Ben Said \\ École Supérieure de Commerce de Tunis, Université de Manouba Tunisie \\ Received: 7 April 2020. Revision received: 13 May 2020. Accepted: 17 May 2020.
}

\begin{abstract}
A statistical analysis based on a tripartite theoretical model of tourist attraction was conducted in this work to examine the influence of personal factors on tourists' perception of the attractions that determine a city's attractiveness. Using the responses of a sample of 510 international tourists, a random sample of 171 was selected, from which parametric and non-parametric tests were carried out: Levene's test, Kruskal-Wallis test and Mann-Whitney test. The results show that, from a statistical point of view, there are statistically significant relationships between tourist perception and personal factors. This reveals that the same tourist attractions can be perceived and evaluated differently according to gender, age, motivation, and region of origin. Thus, there is a significant influence of internal factors on the tourists' perception. Tourism perception is therefore not static but fluctuating. Consequently, it is imperative for decision-makers to segment the tourism market to satisfy tourists, meet their expectations, and enhance the attractiveness of a destination. The main results of this research are related to the contrasting perceptions of the same tourist attraction by different groups of tourists. An exploration that has so far not been carried out in previous research, in the context of urban tourism. Thus, tourism managers should take this variation into account when planning a tourism marketing and communication strategy. Research proves that targeted and focused tourist development can increase the tourist attractiveness of a city, the level of which depends crucially on perception. Finally, a presentation of four models that categorize and prioritize tourist attractions according to preferences by age, gender, motivation, and original destination is presented. These models are put forward as a referential, decision-support framework that clarifies the nuanced preferences of different tourist groups. The theoretical and marketing implications of this work are also discussed for further research and development of tourism destination management.
\end{abstract}

Key Words: Urban Tourism, City Attractiveness, Tourists' Perception, Market segmentation, Personal factors.

JEL Classification: Z32, Z38, J42, L833

Reference: Chebli, A., Chabou Othmani, M. \& Ben Said, F. (2020). Market Segmentation in Urban Tourism: Exploring the Influence of Personal Factors on Tourists' Perception. Journal of Tourism and Services, 20(11), 74-108. doi: 10.29036/jots.v11i20.144 


\section{JOURNAL OF TOURISM AND SERVICES}

Issue 20, volume 11, ISSN 1804-5650 (Online)

www.jots.cz

\section{Introduction}

Since the 1980s, a new model of urban management, marked by the features of neo-liberalism, has emerged. Therefore, a liberal urbanism has been developed (Oakley, 2016; Clavé-Mercier, 2017; Lin, 2017), based on a creative economy and consumption. Cities are thus changing nuances, betting everything on attractiveness, described as a new doctrine to support their growth and escape regression (Terrin, 2014). Davezies (2004) clearly expressed this idea: "the challenge of territorial development is not to create as much wealth as possible, but to capture as much as possible". The city seeks to "attract consumers who will spend on its territory" (Ignalina \& Park, 2005); and to address this challenge, it focusses on tourism.

Tourism is both a lever for innovation and a component of attractiveness. It is a contemporary element enabling cities to be recreated, through a new "way of doing" things; a reshaping by shopping, culture, leisure, business and events (Kadri \& Pilette, 2017). Tourism is therefore an important source of income for many cities. It offers great potential for economic, social and spatial development (Ashworth, 2012). The growing importance of smart digital technologies within urban infrastructure is portrayed by Kearney et al. (2019). This explains the eagerness of many destinations to develop this industry.

As a result, multitudes of new destinations are emerging, which tends to exacerbate competition between and within regions (Horita, 2017; Salama \& Oláh, 2019). However, territories must plan an effective and sustainable tourism attraction strategy to enhance the value of tourism and ensure strategic positioning. According to several authors (Hu \& Ritchie, 1993; Kim, 1998; Ritchie \& Zins, 1978; Das et al., 2007), tourist attractiveness is a function of the tourist's perception of the destination's ability to satisfy their needs and provide them with personal benefits (Mayo \& Jarvis, 1980). This definition states that to maintain an appropriate level of attractiveness, a proven knowledge of tourist preferences is required in order to meet their expectations and satisfy their needs.

A consumer's preference for a product is influenced by perception (Goodrich, 1978). However, what is perceived as important to one traveler may not be important to another. The relative importance a tourist places on the attributes that determine the attractiveness of a tourist destination is therefore not a static datum. This importance judgment depends on his/her perception, which is in turn influenced by various contextual factors, whether internal or external (Leiper, 1990; Kim \& Perdue, 2011; Rajesh, 2013). Understanding the impact of these factors on the tourists' perception is an advantage, which will help marketers to better identify consumer profiles. According to Heung and Quf (2000), understanding travel preferences and tourist behavior is essential for tourism marketing in terms of market segmentation and designing an effective promotional campaign. On the other hand, obtaining this information allows planners to design specific products that are more tailored to demand, and thus create the optimal conditions for unforgettable touristic experiences.

Despite the importance of this topic, only a few studies have examined the influence of personal factors on tourism perception (Beerli \& Martin, 2004; Rasoolimanesh \& al., 2019). Therefore, the objective of this paper is to provide an important contribution to the literature on the perception of tourist attractiveness. This research aims to develop a methodological framework to discuss the role of the contextual approach in assessing the importance of tourist attributes and their contribution to the attractiveness of cities. The results of this examination allow a segmentation of the urban tourism market. The study focuses on the analysis of the impact of personal factors on the perception of tourist attractions by tourists. The remainder of the paper describes the methodology of data collection, the population studied, followed by a description of the statistical tests used.

\section{Literature review}




\section{JOURNAL OF TOURISM AND SERVICES}

Issue 20, volume 11, ISSN 1804-5650 (Online)

www.jots.cz

According to Krešić \& Prebezac (2011), tourist attractiveness is a mental construction that exists only in the mind of potential visitors. It is the cognitive representation of a person's knowledge, feelings and overall perception of a particular destination. Tourist attractiveness was defined by Mayo and Jarvis (1981) as the feelings and opinions of its visitors about the destination's perceived ability to satisfy their needs (Vengesayi, 2003). This concept explores the relationship between supply and demand "Graph 1" (Iațu \& Bulai, 2011).

As for the supply side, tourist attractions represent the basic resources that shape the tourist attractiveness system. The tourism industry is built on these resources (Gunn, 1972; Lew, 1987; Leiper, 1990, Buhalis, 2000; Hakeem et al., 2018). The degree of attractiveness and the extent of a territory's influence increases, all the more so as the mosaic of forms it exhibits is varied, and vice versa. In general, oversized, grandiose, broadly spread shapes and spatially distributed are attractive and appealing to the observer (Cocean, 2011). From a perspective demand, researchers have argued that the more a destination is able to meet the tourists' needs, the more attractive it is (Cugno et al., 2012).

\section{Graph 1: Basic component of attractiveness.}

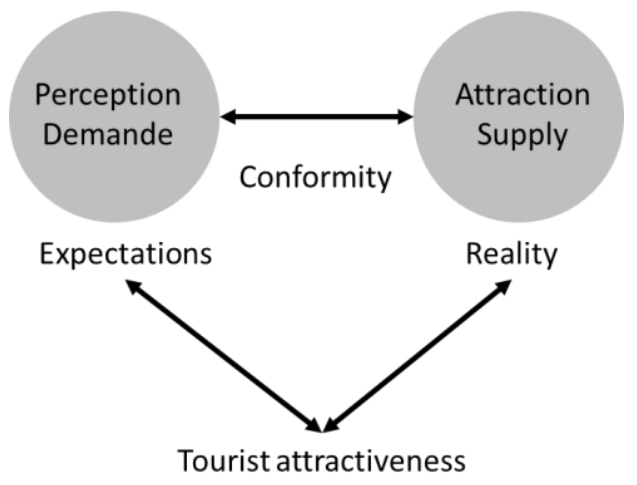

Source: Author own conception

Tourist attractiveness is considered as a resilience strategy (Khomsi, 2018; Delaplaceadri et al., 2018), and since the 1980s, tourism has been introduced by many cities as an urban function to recover after the industrial crisis (Ohanyan \& Androniceanu, 2017). Therefore, it is perceived as a regeneration strategy (Law, 1999; Cave \& Jolliffe, 2012; Kadri, 2007; Kadri \& Pilette, 2017). Moreover, it is an industry in full expansion. Statistics attest that during the period 2009-2013, the urban escapism rate increased by 47\% (Terzibasoglu, 2015).

Urban tourism is considered as a strategic project that generates growth (Androniceanu et al., 2019). It provides several different advantages: economic, social and spatial (Ashworth \& Page, 2011; Pearce, 2001). Thus, cities aim to develop this profitable activity and the result is the emergence of a multitude of new destinations, increasing competition between cities (Kresic \& Prebezac, 2011). Faced with this strong tourist competitiveness, cities must plan an effective and sustainable tourist attraction strategy to find their way in a saturated market.

Furthermore, when discussing about tourist attractiveness, it should be mentioned that this system is mainly based on tourist attractions. According to Gunn definition, the tourist attraction is the central element from which the tourism system develops. In fact, without it, there would be no tourism and therefore no tourism supply (Gunn, 1972). For Lew (1987) and Leiper (1990), a tourist attraction includes all the elements of a "non-family" place that attracts discretionary travelers away from home. Gearing (1974) pioneered a categorization of tourist attractions, consisting of five groups, each group divided into sub-types. This categorization is commonly used in tourism literature (Table 1). 


\section{JOURNAL OF TOURISM AND SERVICES}

Issue 20, volume 11, ISSN 1804-5650 (Online)

www.jots.cz

Table 1. Group of touristic attractions

\begin{tabular}{|l|l|}
\hline \multicolumn{1}{|c|}{ ATTRACTIONS } & \multicolumn{1}{c|}{ SUBGROUPS } \\
\hline Natural factors & $\begin{array}{l}\text { Nature beauty of the landscape } \\
\text { climate, }\end{array}$ \\
\hline Social factors, & Artistic and architectural features \\
& Distinctive local features \\
& Fair and exhibits \\
& Attitudes towards tourist \\
\hline Historical factors & Ancient ruin \\
& Religious significance \\
& Historical prominence \\
\hline Recreational and shopping facilities & Sport facilities \\
& Educational facilities \\
& Facilities conductive to health \\
& Nighttime recreation \\
& Shopping facilities \\
\hline Infrastructure, food, and shelter & Infrastructure above minimal touristic quality \\
& (road, water, electricity, safety...etc.) \\
& Food and lodging facilities s \\
\hline
\end{tabular}

Source: Gearing (1974)

Decision-makers need to have an in-depth knowledge of what constitutes a potential tourist attraction and to understand the expectations of travelers to define a cutting-edge strategy. Such information is the basis for a successful tourism development process. So, to successfully develop a tourism strategy, what are the attractions that make cities attractive?

Table 2. Urban tourist attractions

\begin{tabular}{|l|l|}
\hline \multicolumn{2}{|c|}{ PRIMARY ELEMENTS } \\
\hline Activity Place & Leisure Setting \\
Cultural Facilities & Physical Characteristics \\
- Museums and Art Galleries & - Historical Street Pattern \\
- Theaters and Cinemas & - Interesting Buildings \\
- Concert Halls & - Ancients Monuments and Statues \\
- Convention Centers & - Parks and Green Areas \\
- Other Visitor Attractions & - Waterfronts (Harbor, Canal, River) \\
Sport Facilities & Socio-Cultural Features \\
- Indoor and Outdoor & - Liveliness of the Place \\
Amusement Facilities & - Language \\
- Night Clubs & - Local Customs and Costumes \\
- Casinos and Bingo Halls & - Cultural Heritage \\
- Festivals Events & - Friendliness \\
\hline \multicolumn{1}{|c|}{ SECONDARY ELEMENTS } & - Security \\
\hline - Accommodation & \multicolumn{1}{|c|}{ ADDITIONAL ELEMENTS } \\
- Catering Facilities & - Accessibility \\
- Shopping & - Transportation and Parking \\
- Markets & - Tourist Information \\
\hline
\end{tabular}

Source: Jansen-Verbeke (1986) 


\section{JOURNAL OF TOURISM AND SERVICES}

Issue 20, volume 11, ISSN 1804-5650 (Online)

www.jots.cz

Jansen-Verbeke (1986) presented a model of urban tourist attraction. The author listed and hierarchized in three levels the main attractive elements of a city: primary, secondary and additional attractions (Table 2). Afterwards, several authors have used this model in their work (Law, 1992; Ariani, 2018). However, the representation of the attractions, put forward by Myriam Jansen-Verbose, was based on a geographical approach. According to Alan Lew (1987), this approach is the most common way of conceptualizing attractions. It is based on a nominal inventory that simply divides the attractions into two groups: natural (flora, fauna and climate) and cultural (history, populations and monuments).

The hierarchy presented by the author does not take into account the study of perception, although perception has a direct influence on preferences and intervenes consistently in the decisionmaking process (Decrop, 2011). In fact, there is no model hierarchy of tourist attractions; each tourist makes his/her own hierarchy, according to his/her perception (Leiper, 1990; Botti \& al., 2002).

According to Leiper (1990), tourist attractions are subject to different degrees of significance, as some attractions are more important than others to a tourist. A tourist's perception is therefore the element of judgement, on the basis of which attractions are ranked. Furthermore, Leiper argued that the attraction classification should be made on the basis of a three-level model (primary, secondary, tertiary or complementary). This classification allows a better explanation and understanding of tourist behavior, and a segmentation of the urban tourism market. Hence, managers can create different products and experiences according to the interests and values of consumers (Page, 2003).

Nonetheless, a hierarchy of urban tourist attractions that takes into consideration the cognitive aspect would be interesting. It will help decision-makers to better identify tourist profiles and to develop more targeted products. At the city level, a substantial flow of visitors coexists, with broad and heterogeneous motivations and interests, which makes the opinions about a tourist attraction vary (Bramwelle, 1998; Ashworth, 2012, Bovin, 2019). As a result, tourist attractions do not have equal value and influence the attractiveness system to various degrees. Some attractions are more important than others and this assessment depends on the perception of the visitors.

Perception can be defined as the process by which an individual selects, organizes and interprets stimuli to obtain a meaningful and coherent picture of the destination (Jordaan \& Prinsloo, 2001; SerkanVolkan, 2013). Perception has a subjective meaning, which gives it an unstable character. Conceptually, three factors influence perception: internal psychological factors, external destination factors (especially destination images) and situational constraints (Kim \& Perdue, 2011; Das \& al., 2017). Personal factors are divided into two sections: socio-demographic characteristics and psychological characteristics (Martin, 2004). Socio-demographic characteristics include sex, age, education, family life, social class, place of residence, occupation, income, marital status and country of origin. Psychological factors include motivations, values, personality, lifestyle, needs, past experiences, prior knowledge, preferences and satisfaction (Rajesh, 2013; Rasoolimanesh \& al., 2019).

Despite the importance of this study question, only a few studies have examined the influence of these factors on the tourists' perception (Beerli \& Martin, 2004; Rasoolimanesh \& al., 2019). However, in terms of perception of an urban recreation context and the appreciation of those resources, much is still unknown. Since attractiveness depends on visitors' psychological and socio-economic factors, it is probable that not all persons who go to a city for tourist purposes, will have the same level of expectation regarding tourist attractions. Thus, four hypotheses are put forward to study this interaction. The hypotheses illustrate the effects of these factors on the perception of tourist attractions, and in this case on the level of attractiveness.

Hb1: Gender has a significant influence on the perception of urban tourist attractions, $\mathrm{Hb}$ : Age has a significant influence on the perception of urban tourist attractions, Hb3: Tourist motivation significantly influences the perception of urban tourist attractions, $\mathrm{Hb} 4$ : Geographic region of origin has a significant influence on the perception of urban tourist attractions. 


\section{JOURNAL OF TOURISM AND SERVICES}

Issue 20, volume 11, ISSN 1804-5650 (Online)

www.jots.cz

\section{Methods}

This research adopts five steps to assess the impact of personal factors on the perception of touristic attractions,

Step 1: Selection of study variables

The selection of study variables were derived on the basis of two theoretical models of Gearing $\&$ al. (1974) and Jansen-Verbeke, (1986), see tables1 and 2.

\section{Step 2: Conception and dissemination of investigative instruments}

The questionnaire conceived for this study is divided into three parts (Appendix A). The first part presents general information on the subject. The aim is to explain the objectives of this work to the respondents. In the second part, factual questions are asked, which allowed to clearly identify the socioeconomic dimensions of the respondents and to identify certain factors that potentially influence the tourists' perception. The third and final section aims to determine the importance of various attractions that determine the tourist attractiveness of cities. The relative importance of the attractions was measured on the basis of 23 attributes which represent study variables, and which were defined at the first step. Respondents were asked to indicate the importance they attach to these attractions when planning their trip. The importance given to the attractions was measured on a five-point Likret scale, ranging from 1: not at all important to 5: very important.

A self-administered survey instrument was favored for this research project, for two reasons: first, it has the potential to be disseminated geographically on a large scale, thus targeting respondents from around the country, as was the case in this study. The second reason is financial, considering the limited financial condition, dissemination via digital platform is an affordable and excellent distribution alternative for collecting quantitative data.

\section{Step 3. Data collection}

Quantitative data was collected based on a questionnaire (Appendix A), to test the hypotheses and meet the objectives of this research. The choice of a qualitative survey allows us to measure personal, subjective experiences and to explain certain (aspects of) social phenomena such as (preferences) of various individuals. The measurement process enables us to obtain valid and objective knowledge (Chazel $\&$ al, 1970).

The survey was carried out among international travelers who had previously visited cities on their past trips. The aim is to present several syntheses and discussions on the perception of attractions that tourists consider important for the attractiveness of cities in general, rather than to assess the attractiveness of destinations per se. The Cranach's Alpha test was conducted once the questionnaire was sent to twenty $(n=20)$ respondents to test the reliability of the measurement instrument. The value of coefficient is 0.96 , which is considered a satisfactory value in fundamental research (Nunnaly, 1978).

\section{Step 4. Study sample}

A sampling frame, consisting of 514 questionnaires, was collected from an extensive collection. The survey was conducted from July 2019 to November 2019. The five-point Likert scale was used as the response format, ranging from 1: not at all important, to 5: very important. The recovered data showed that the dominant respondent group was the African segment of the population.

A simple random sample was chosen to ensure a fairly orderly and consistent group and an unbiased representation of reality. The size of the calculated random sample is 171 ; this sample covers the study population in a very balanced way. Although this is a small sample, the parameters associated with it, the margin of error is $7.6 \%$ and the confidence level is $95 \%$, confirm its reliability and the representativeness of the results obtained.

\section{Step 5. Data analysis}

The data was analyzed using a statistical software (Spss for Windows). First, a parametric and two non-parametric tests were used (Levene's test, Kruskal-Wallis test and Mann-Whitney test) to test these hypotheses and to study the relationship between perception variables and personal factors. After, a 


\section{JOURNAL OF TOURISM AND SERVICES}

Issue 20, volume 11, ISSN 1804-5650 (Online)

www.jots.cz

correspondence factor analysis (CFA) was developed. This descriptive statistical analysis allowed to simultaneously study the relationship between perception variables and personal factors. Thus, the analysis predicted the preferences of the different tourist groups studied, otherwise identify discriminating groups. The Alpha Cranach value was referenced to confirm the results of the factor analysis.

\section{Results}

\subsection{Tourists' demographic profile}

Table 3 summarizes information on the profile of respondents with respect to gender, age, travel motivation and regional origin of tourists.

Table 3. Demographic profile of respondents.

\begin{tabular}{|c|c|c|}
\hline Demographic characteristics & Categories & Percentage \\
\hline Gender & $\begin{array}{l}\text { - Woman } \\
\text { - Man }\end{array}$ & $\begin{array}{ll}\text { - } & 74.26 \% \\
\text { - } & 25.73 \%\end{array}$ \\
\hline Age group & $\begin{array}{ll}\text { - } & \text { Under } 18 \text { years old } \\
\text { - } & 18-24 \text { years old } \\
\text { - } & 25-34 \text { years old } \\
\text { - } & 35-49 \text { years old } \\
\text { - } & 50-65 \text { years old } \\
\end{array}$ & $\begin{array}{ll} & 4.76 \% \\
\text { - } & 23.97 \% \\
\text { - } & 39.75 \% \\
\text { - } & 24.56 \% \\
\text { - } & 7.01 \% \\
\end{array}$ \\
\hline Travel motivation & $\begin{array}{ll}\text { - } & \text { Leisure/recreation } \\
\text { Business (Conferences, } \\
\text { professional internships, } \\
\text { scholarships) }\end{array}$ & $\begin{array}{ll}\text { - } & 80.29 \% \\
\text { - } & 19.29 \%\end{array}$ \\
\hline Regional origin of tourists & $\begin{array}{ll}\text { - } & \text { Africa } \\
\text { - } & \text { America } \\
\text { - } & \text { Asia Pacific } \\
\text { - } & \text { Europe } \\
\end{array}$ & $\begin{array}{ll} & 58.47 \% \\
\text { - } & 8.77 \% \\
\text { - } & 7.01 \% \\
\text { - } & 25.7 \% \\
\end{array}$ \\
\hline
\end{tabular}

Source: Authors, statistical analysis results

Most of the respondents are between 25-34 years old (39.75\%). The sample includes more women $(74.26 \%)$ than men, who represent $25.14 \%$ of the sample. The majority of them $(80.29 \%)$, during their last urban trip, were motivated to travel for leisure (cultural tourism, shopping, visiting friends/families, etc.).

\subsection{Influence of personal factors on tourist perception}

\subsubsection{Gender and tourist perception}

The Levene's test was used to study the influence of gender on perception. This test allowed to determine whether or not the perception of the variables by both groups is identical. Two hypotheses were tested:

H0: The variances are identical;

Ha: At least one of the variances is different. 


\section{JOURNAL OF TOURISM AND SERVICES}

Issue 20, volume 11, ISSN 1804-5650 (Online)

www.jots.cz

The variance comparison results agree to reject the null hypothesis H0 "Table 11, Appendix B". As the $\mathrm{p}$-value calculated for ethnography and folklore is $\mathrm{p}$-value $=.016$, sports facilities and equipment $\mathrm{p}$-value $=.004$, quality/price ratio $\mathrm{p}$-value $=.053$ and transportation diversity $\mathrm{p}$-value $=.046$, is lower than the significance level alpha $=0.05$, the null hypothesis $\mathrm{H} 0$ must be rejected and the alternative hypothesis $\mathrm{Ha}$ must be retained. Thus, it is proven that gender has a significant influence on the tourist's perception. The hypothesis $\mathrm{Ha}$ is then valid.

Only the four most significant variables were projected to obtain a readable projection. The analysis space reduced those variables "Graph 2" into two main factors "Table 4". The reliability analysis of this factor analysis is satisfactory, given that the alpha value is equal to 0.619 . The percentage of variance cumulated by the two factors is satisfactory. It reaches $79.2 \%$, and represents more than half of the information (Table4).

Table 4. MCA model summary based on gender

\begin{tabular}{|c|c|c|c|c|}
\hline \multicolumn{5}{|c|}{ Model summary } \\
\hline \multirow{2}{*}{ Dimension } & \multirow{2}{*}{$\begin{array}{l}\text { Cronbach's } \\
\text { Alpha }\end{array}$} & \multicolumn{3}{|c|}{ Variance accounted for } \\
\hline & & $\begin{array}{l}\text { Total } \\
\text { (Eigenvalue) }\end{array}$ & Inertia & $\%$ of variance \\
\hline 1 & .711 & 2.321 & .464 & 46.422 \\
\hline 2 & .488 & 1.640 & .328 & 32.805 \\
\hline Total & & 3.961 & .792 & \\
\hline Mean & .619a & 1.981 & .396 & 39.613 \\
\hline
\end{tabular}

Source: Authors, processing in the Spss software

Graph 2. Discriminating variables: gender

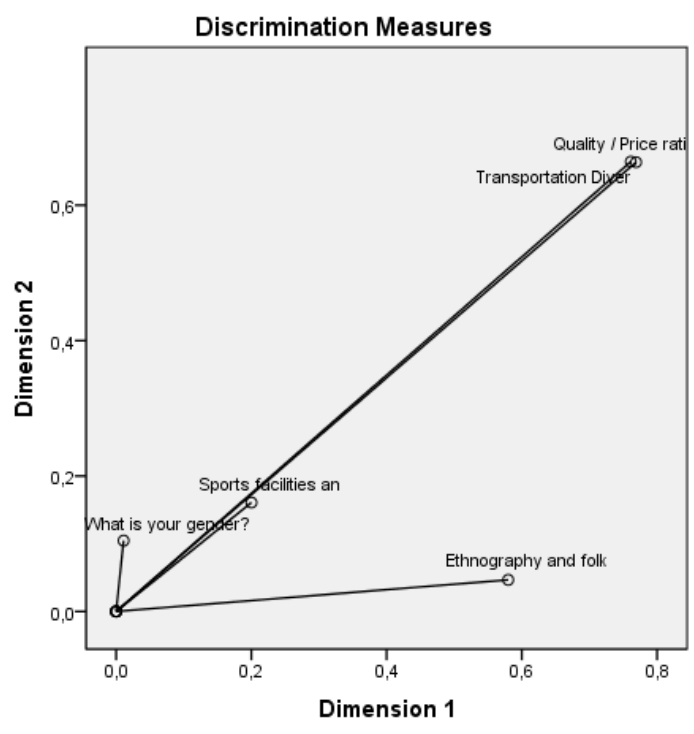

Source: Authors, processing in the SPSS software

Graph 3 shows the existence of two forms of opposition. Firstly, the first factor, represented on the horizontal axis, opposes men and women from a perceptual point of view. The second factor shown on the vertical axis, suggests a second principle of opposition related to the level of judgement and preference that changes according to gender. It can be observed that women attach much importance to 


\section{JOURNAL OF TOURISM AND SERVICES}

Issue 20, volume 11, ISSN 1804-5650 (Online)

www.jots.cz

the diversity of means of transport and folklore, unlike men. On the same projection, it appears that sports facilities are identified as important for men, and not at all important for women.

\section{Graph 3. Gender composite plane with MCA}

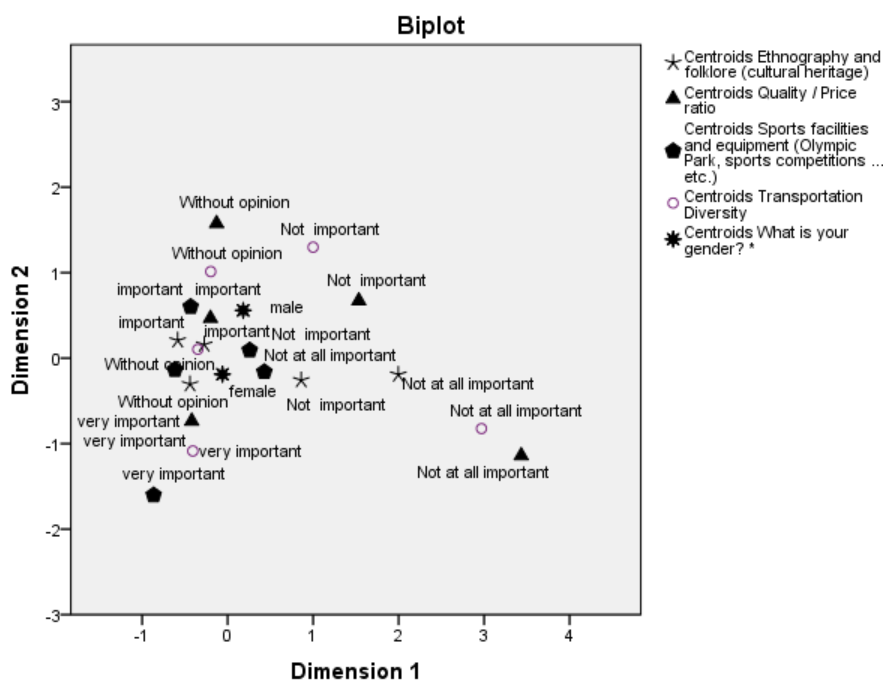

Source: Authors, processing in the SPSS software

\subsubsection{Age and tourist perception}

The Kruskall Wallis test was applied to test the existence of a relation between the age factor, which is ordinal, and the variables of tourism perception. It tests the null hypothesis of the absence of a link between age and perceptions against the alternative hypothesis of the existence of a link between age and perceptions (Table 5).

Table 5. Kruskall Wallis results test based on age

\begin{tabular}{|l|l|l|l|}
\hline Variables (Attractions) & Chi-square & $\mathrm{df}$ & $\begin{array}{l}\text { asymptotic } \\
\text { significance }\end{array}$ \\
\hline Climate & 7.235 & 5 & .204 \\
\hline Architecture and Urban Ambience & 1.490 & 5 & .914 \\
\hline Ethnography and folklore (cultural heritage) & 2.435 & 5 & .786 \\
\hline Professional and event organizations & 6.672 & 5 & .246 \\
\hline Sports facilities and equipment & 6.685 & 5 & .245 \\
\hline Historic Monuments. World Heritage & 3.565 & 5 & .614 \\
\hline Historic Dominance and FAMOUS PEOPLE & 6.840 & 5 & .233 \\
\hline Public places & 2.081 & 5 & .838 \\
\hline Shopping Resources & 4.914 & 5 & .426 \\
\hline Night life & 7.290 & 5 & .200 \\
\hline Security & $\mathbf{1 0 . 5 1 4}$ & 5 & .062 \\
\hline Friendliness and hospitality & 9.073 & 5 & .106 \\
\hline Accessibility to health services & $\mathbf{1 7 . 4 6 4}$ & 5 & $\mathbf{. 0 0 4}$ \\
\hline Clean environment & 6.983 & 5 & .222 \\
\hline Quality / Price ratio & 5.378 & 5 & .372 \\
\hline
\end{tabular}




\section{JOURNAL OF TOURISM AND SERVICES}

Issue 20, volume 11, ISSN 1804-5650 (Online)

www.jots.cz

\begin{tabular}{|l|l|l|l|}
\hline Assistance services & 4.527 & 5 & .476 \\
\hline The language spoken in the host destination & 8.285 & 5 & .141 \\
\hline Transport infrastructure & 3.976 & 5 & .553 \\
\hline Transportation Diversity & 2.761 & 5 & .737 \\
\hline Diversity of tourist accommodation & .950 & 5 & .966 \\
\hline The quality of the restoration & 4.160 & 5 & .527 \\
\hline High-tech development & $\mathbf{9 . 3 8 1}$ & 5 & $\mathbf{. 0 9 5}$ \\
\hline Advertising, promotion of the tourist destination & 5.091 & 5 & .405 \\
\hline
\end{tabular}

Source: Authors, processing in the Spss software

The results of the Kruskall Wallis test show that three variables are significantly influenced by the age factor: security variable $\left(\chi^{\wedge} 2=10,514\right.$ and $p$-value $\left.=.062\right)$, accessibility to the health service $\left(\chi^{\wedge} 2=\right.$ $17,464$ and $\mathrm{p}$-value $=.004)$, and technology $\left(\chi^{\wedge} 2=9,381\right.$ and $\mathrm{p}$-value $\left.=.095\right)$. The $\mathrm{p}$-value of these three variables confirms our hypothesis that age has an influence on the tourists' perception, which is in line with the findings of other researchers (Baloglu \& McCleary, 2000; Neethiahnanthan \& al., 2014). In addition, a correspondence factor analysis (MCA) was performed to visualize the touristic preferences of different age groups (Tabel 6, Graph 4).

Table 6. MCA model summary based on Age

\begin{tabular}{|l|l|l|l|l|}
\hline \multicolumn{5}{|c|}{ Model summary } \\
\hline Dimension & $\begin{array}{l}\text { Cronbach's } \\
\text { alpha }\end{array}$ & \multicolumn{2}{|l|}{ Variance represented } \\
\cline { 3 - 5 } & $\begin{array}{l}\text { Total } \\
\text { (Eigenvalue) }\end{array}$ & Inertia & $\begin{array}{l}\text { \% of the } \\
\text { variance }\end{array}$ \\
\hline 1 & .651 & 1.955 & .489 & 48.873 \\
\hline 2 & .461 & 1.529 & .382 & 38.229 \\
\hline Total & 3.484 & .871 & \\
\hline Mean & $.568^{a}$ & 1.742 & .436 & 43.551 \\
\hline \multicolumn{5}{|l|}{ a. Cronbach's alpha average is based on the mean eigenvalue } \\
\hline
\end{tabular}

Source: Authors, processing in the Spss software

\section{Graph 4. Discriminating variables: Age}

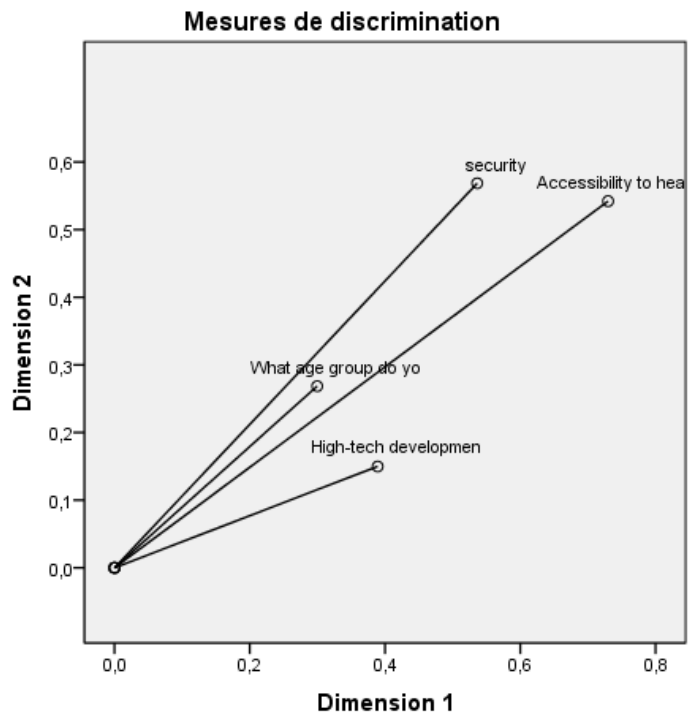

Source: Authors, processing in the Spss software 


\section{JOURNAL OF TOURISM AND SERVICES}

Issue 20, volume 11, ISSN 1804-5650 (Online)

www.jots.cz

The analysis of the reliability of this factorial analysis which consists in reducing the analysis space composed of 4 items to two main factors is satisfactory, given that the value of Cronbach's alpha is 0.56, and allows to recover $87 \%$ of the initial inertia. This value is qualified as satisfactory and indicates that our factorial analysis is relevant and reliable.

The most discriminating variables for tourists' perception according to age are safety and accessibility to health services "Graph 4".

The analysis of the projection of the variables on the composite level by the two main factors shows that axis 2 represents the importance component. This component indicates that the older the tourist group is, the lower the importance given to the variables. The younger the age of the tourists, the greater the importance given to the different variables simultaneously. Analysis of Axis 1 shows that young people are more sensitive to safety, accessibility to health services and high-tech services "Graph $5 "$.

\section{Graph 5. Age composite plane with MCA}

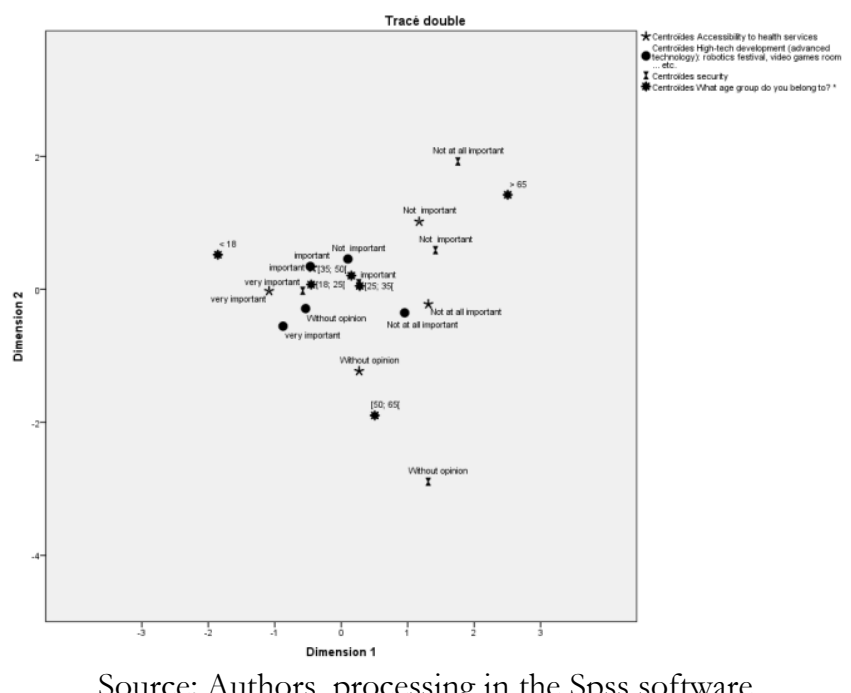

\subsubsection{Motivation and perceptions}

The Mann-Whitney test allows to test the dependence between a dichotomous variable which is the motive and tourists' perception. It is an ordinal variable. The null hypothesis of this test represents the absence of a link between the two variables and the alternative hypothesis indicates that there is a link between the motive and the importance given to different modalities. "Table 7" summarizes the results of this test.

Table 7. Mann-Whitney test results based on Motivation

\begin{tabular}{|l|l|l|l|l|}
\cline { 2 - 5 } \multicolumn{1}{c|}{} & $\begin{array}{l}\text { Mann- } \\
\text { Whitney } \\
\text { U }\end{array}$ & $\begin{array}{l}\text { Wilcoxon } \\
\text { W }\end{array}$ & Z & $\begin{array}{l}\text { Asymp. sig ( } \\
\text { 2-tailed) }\end{array}$ \\
\hline Climate & 1851.000 & 2412.000 & -1.763 & .078 \\
\hline Architecture and Urban Ambience & 1737.500 & 2298.500 & -2.302 & .021 \\
\hline $\begin{array}{l}\text { Ethnography and folklore (cultural } \\
\text { heritage) }\end{array}$ & 1764.500 & 2325.500 & -2.102 & .036 \\
\hline Professional and event organizations & 1282.500 & 10873.500 & -4.025 & .000 \\
\hline Sports facilities and equipment & 1872.500 & 11463.500 & -1.644 & .100 \\
\hline
\end{tabular}




\section{JOURNAL OF TOURISM AND SERVICES}

Issue 20, volume 11, ISSN 1804-5650 (Online)

www.jots.cz

\begin{tabular}{|l|l|l|l|l|}
\hline Historic Monuments, World Heritage & 2185.000 & 2746.000 & -.384 & .701 \\
\hline $\begin{array}{l}\text { Historic Dominance and FAMOUS } \\
\text { PEOPLE }\end{array}$ & 2011.000 & 2572.000 & -1.101 & .271 \\
\hline Public places & 1945.000 & 2506.000 & -1.404 & .160 \\
\hline Shopping Resources & 2173.500 & 11764.500 & -.423 & .672 \\
\hline Night life & 2274.000 & 11865.000 & -.012 & .990 \\
\hline Security & 2256.500 & 11847.500 & -.089 & .929 \\
\hline Friendliness and hospitality & 2268.000 & 2829.000 & -.037 & .970 \\
\hline Accessibility to health services & 2058.000 & 11649.000 & -.881 & .378 \\
\hline Clean environment & 2171.000 & 11762.000 & -.444 & .657 \\
\hline Quality / Price ratio & 2209.500 & 2770.500 & -.282 & .778 \\
\hline Assistance services & 2108.000 & 11699.000 & -.685 & .493 \\
\hline $\begin{array}{l}\text { The language spoken in the host } \\
\text { destination }\end{array}$ & 1572.500 & 11163.500 & -2.824 & .005 \\
\hline Transport infrastructure & 2192.000 & 11783.000 & -.359 & .719 \\
\hline Transportation Diversity & 2119.000 & 11710.000 & -.653 & .514 \\
\hline Diversity of tourist accommodation & 2188.000 & 11779.000 & -.369 & .712 \\
\hline The quality of the restoration & 2110.000 & 2671.000 & -.679 & .497 \\
\hline High-tech development & 1908.500 & 11499.500 & -1.482 & .138 \\
\hline $\begin{array}{l}\text { Advertising, promotion of the tourist } \\
\text { destination }\end{array}$ & 2081.500 & 11672.500 & -.784 & .433 \\
\hline
\end{tabular}

Source: Authors, processing in the Spss software

The results of this test show that there is a significant dependence between the travel motive and four variables, which are: climate $(Z=-1,763$ and $p$-value $=0.078)$, architecture and urban atmosphere $(\mathrm{Z}=-1,763$ and $\mathrm{p}$-value $=0.021)$, ethnography and folklore $(\mathrm{Z}=-2,102$ and $\mathrm{p}$-value $=0.36)$. Professional and event organizations $(\mathrm{Z}=-4,025$ and $\mathrm{p}$-value $=.000)$, the language spoken in the host destination $(\mathrm{Z}=$ $2,824$ and $\mathrm{p}$-value $=.005)$. The MCA factor analysis allows to illustrate the link between these four variables and the travel motives (Table 8 , Graph 6).

Table 8.MCA model summary based on Motivation

\begin{tabular}{|c|c|c|c|c|}
\hline \multicolumn{5}{|c|}{ Model summary } \\
\hline \multirow[t]{2}{*}{ Dimension } & \multirow{2}{*}{$\begin{array}{l}\text { Cronbach's } \\
\text { alpha }\end{array}$} & \multicolumn{3}{|c|}{ Variance represented } \\
\hline & & $\begin{array}{l}\text { Total } \\
\text { (Eigenvalue) }\end{array}$ & Inertia & $\%$ of variance \\
\hline 1 & .712 & 2.323 & .465 & 46.451 \\
\hline 2 & .463 & 1.588 & .318 & 31.764 \\
\hline Total & & 3.911 & .782 & \\
\hline Mean & $.611^{\mathrm{a}}$ & 1.955 & .391 & 39.108 \\
\hline
\end{tabular}

The analysis of the reliability of this factor analysis, which consists of reducing the analysis space composed of 4 variables to two main factors, is satisfactory. Indeed, the value of Cronbach's alpha is 0.61 , and allows to recover $78 \%$ of the initial inertia. This value is qualified as satisfactory and indicates that our factorial analysis is relevant and reliable. "Graph 6" shows that the most discriminating variables when analyzing the tourists" perception according to travel motives are folklore, architecture and climate. 


\section{JOURNAL OF TOURISM AND SERVICES}

Issue 20, volume 11, ISSN 1804-5650 (Online)

www.jots.cz

\section{Graph 6. Discriminating variables: Motivation}

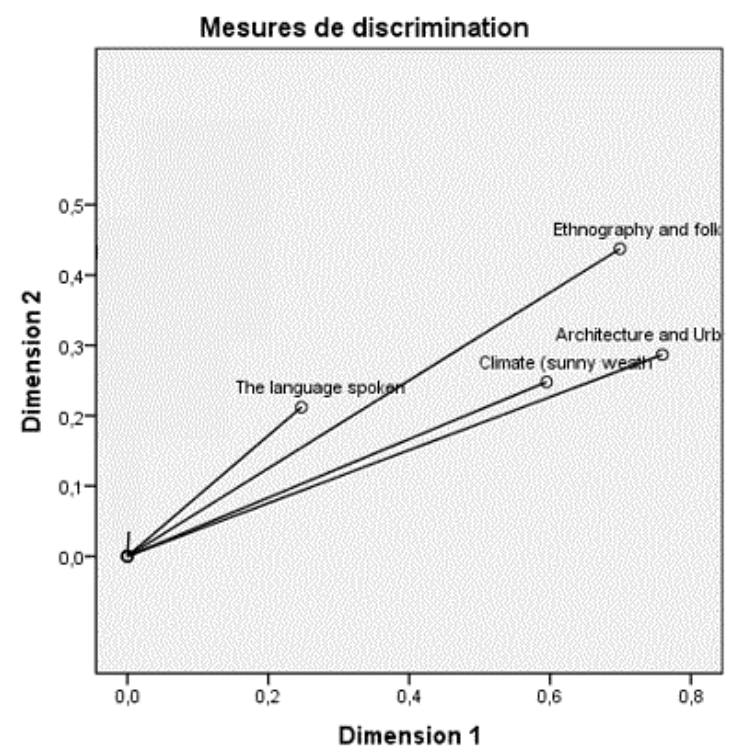

Source: Authors, processing in the Spss software

The analysis of the projection of the variables on the composite level by the two main components shows that tourists whose motive for travel is leisure give more importance to folklore, climate and architecture "Graph 7".

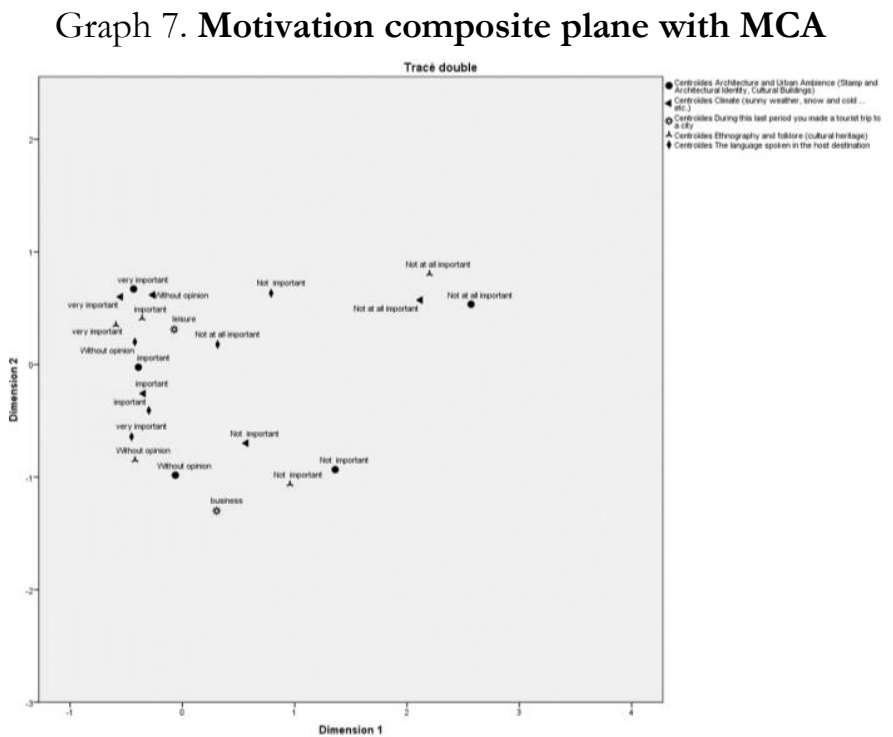

Source: Authors, processing in the Spss software

\subsubsection{Geographic region of origin and perception}

According to the results of the Kruskul test, it appears that geographical origin has an influence on the perception of tourism. 16 variables are significantly influenced by this factor "Table 9". 


\section{JOURNAL OF TOURISM AND SERVICES}

Issue 20, volume 11, ISSN 1804-5650 (Online)

www.jots.cz

Table 9. Kruskul Wallis test results based on Geographic Region of Origin.

\begin{tabular}{|l|l|l|l|}
\hline Variables (Attractions) & Chi-square & df & $\begin{array}{l}\text { asymptotic } \\
\text { significance }\end{array}$ \\
\hline Climate & .896 & 3 & .826 \\
\hline Architecture and Urban Ambience & 2.305 & 3 & .512 \\
\hline Ethnography and folklore (cultural heritage) & 8.266 & 3 & .041 \\
\hline Professional and event organizations & 15.553 & 3 & .001 \\
\hline Sports facilities and equipment & 3.404 & 3 & .333 \\
\hline Historic Monuments, World Heritage & 1.616 & 3 & .656 \\
\hline Historic Dominance and FAMOUS PEOPLE & 1.216 & 3 & .749 \\
\hline Public places & 4.798 & 3 & .187 \\
\hline Shopping Resources & 7.492 & 3 & .058 \\
\hline Night life & 7.789 & 3 & .051 \\
\hline Security & 15.928 & 3 & .001 \\
\hline Friendliness and hospitality & 5.526 & 3 & .137 \\
\hline Accessibility to health services & 16.223 & 3 & .001 \\
\hline Clean environment & 15.860 & 3 & .001 \\
\hline Quality / Price ratio & 9.960 & 3 & .019 \\
\hline Assistance services & 7.326 & 3 & .062 \\
\hline The language spoken in the host destination & 9.005 & 3 & .029 \\
\hline Transport infrastructure & 6.497 & 3 & .090 \\
\hline Transportation Diversity & 7.018 & 3 & .071 \\
\hline Diversity of tourist accommodation & 6.390 & 3 & .094 \\
\hline The quality of the restoration & 12.658 & 3 & .005 \\
\hline High-tech development & 17.139 & 3 & .001 \\
\hline Advertising, promotion of the tourist destination & 10.798 & 3 & .013 \\
\hline & & 3 & \\
\hline
\end{tabular}

Source: Authors, processing in the Spss software

Where: Ethnography and folklore $\left(\chi^{2}=8,266\right.$ et $\mathrm{p}$-value $\left.=0.041\right)$, Professional and event organizations $\left(\chi^{2}=15,553\right.$ et $\mathrm{p}$-value $\left.=0.001\right)$, Shopping resources $\left(\chi^{2}=7,492\right.$ et $\mathrm{p}$-value $\left.=0.058\right)$, Night life $\left(\chi^{2}=7,789\right.$ et $\mathrm{p}$-value $\left.=0.051\right)$, security $\left(\chi^{2}=15,928\right.$ et $\mathrm{p}$-value $\left.=0.01\right)$, Accessibility to health services $\left(\chi^{2}=16,223\right.$ et $\mathrm{p}$-value $\left.=0.001\right)$. clean environement $\left(\chi^{2}=15,860\right.$ et $\mathrm{p}$-value $\left.=0.001\right)$, Quality / Price ratio $\left(\chi^{2}=9,960\right.$ et $\mathrm{p}$-value $\left.=0.019\right)$, Assistance services $\left(\chi^{2}=7,326\right.$ et $\mathrm{p}$-value $\left.=0.062\right)$, The language spoken in the host destination $\left(\chi^{2}=9,005\right.$ et $\mathrm{p}$-value $\left.=0.029\right)$, Transport infrastructure ( $\chi^{2}=6,497$ et $\mathrm{p}$-value $\left.=0.09\right)$. Transportation Diversity $\left(\chi^{2}=7,018\right.$ et $\mathrm{p}$-value $\left.=0.071\right)$, Diversity of tourist accommodation $\left(\chi^{2}=6,390\right.$ et $\mathrm{p}$-value $\left.=0.094\right)$, The quality of the restoration $\left(\chi^{2}=12,658\right.$ et $\mathrm{p}$-value $=0.005)$, High-tech development $\left(\chi^{2}=17,139\right.$ et $\mathrm{p}$-value $\left.=0.001\right)$, Advertising, promotion of the tourist destination $\left(\chi^{2}=10,798\right.$ et p-value $\left.=0.013\right)$.

A MCA provides a synthetic view of the link between perception variables and data on geographical origin, (Table 10). The analysis of the reliability of this factorial analysis, which consists in reducing the space of the analysis composed of 9 items to two main factors, is satisfactory, given that the value of Cronbach's alpha is 0.784 . This value is qualified as satisfactory and indicates that the factorial analysis presented in this study is relevant and reliable. "Graph 8" shows that the most discriminating perceptions depending on the region are the environment, safety and quality of restaurants, and accessibility of health services. 


\section{JOURNAL OF TOURISM AND SERVICES}

Issue 20, volume 11, ISSN 1804-5650 (Online)

www.jots.cz

Table 10. MCA model summary based on geographic region of origin

\begin{tabular}{|l|r|r|r|r|}
\hline \multicolumn{5}{|c|}{ Model summary } \\
\hline \multirow{2}{*}{ Dimension } & \multirow{2}{*}{$\begin{array}{l}\text { Cronbach's } \\
\text { alpha }\end{array}$} & $\begin{array}{c}\text { Variance represented } \\
\text { Total } \\
\text { (Eigenvalue) }\end{array}$ & Inertia & \% of variance \\
\hline 1 & .855 & 4.163 & .463 & 46.251 \\
\hline 2 & .665 & 2.444 & .272 & 27.154 \\
\hline Total & & 6.606 & .734 & \\
\hline Mean & $.784 a$ & 3.303 & .367 & 36.702 \\
\hline \multicolumn{5}{|r|}{ a. Mean Cronbach's Alpha is based on the mean eigenvalue } \\
\hline
\end{tabular}

Source: Authors, processing in the Spss software

\section{Graph 8. Discriminating variables: geographic region of origin}

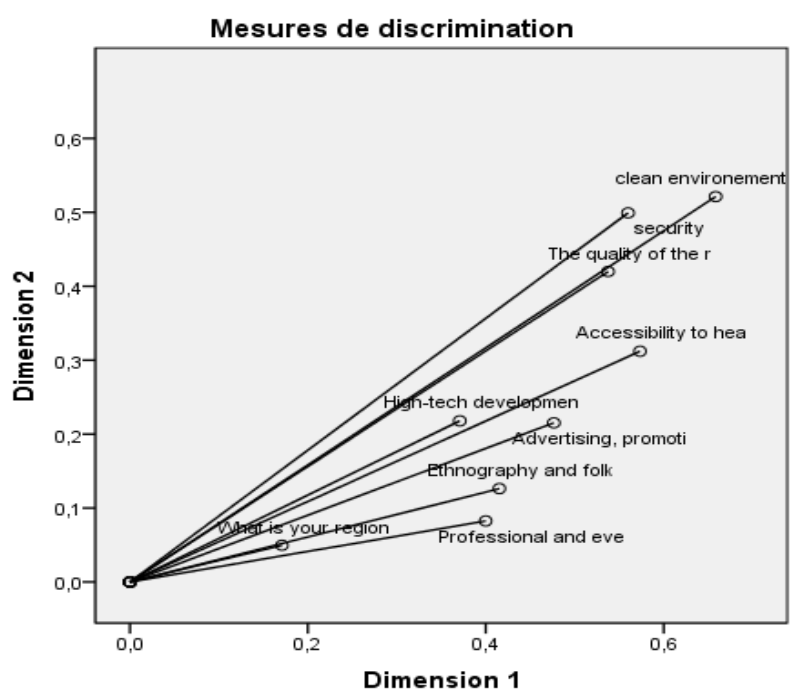

Source: Authors, processing in the Spss software

As shown in "Graph 9", Axis 2, which is considered to be the importance axis, indicates that tourists are either indifferent to all the variables, or they give the same degree of importance to all the variables together. Therefore, all items are complementary. Axis 1 pits Europeans and Asians against Africans and Americans, indicating that Africans and Americans give more importance to the different items than Asians and Europeans. This shows that European and Asian tourists are less demanding than others. The analysis of Axis 2 shows that the preferences of African and Asian tourists differ from those of European and American tourists. Africans and Asians give more importance to the quality of the restoration, promotion and development of high-tech, while Americans and Europeans give more importance to safety and folklore. 


\section{JOURNAL OF TOURISM AND SERVICES}

Issue 20, volume 11, ISSN 1804-5650 (Online)

www.jots.cz

Graph 9. Composite plane of geographic region of origin

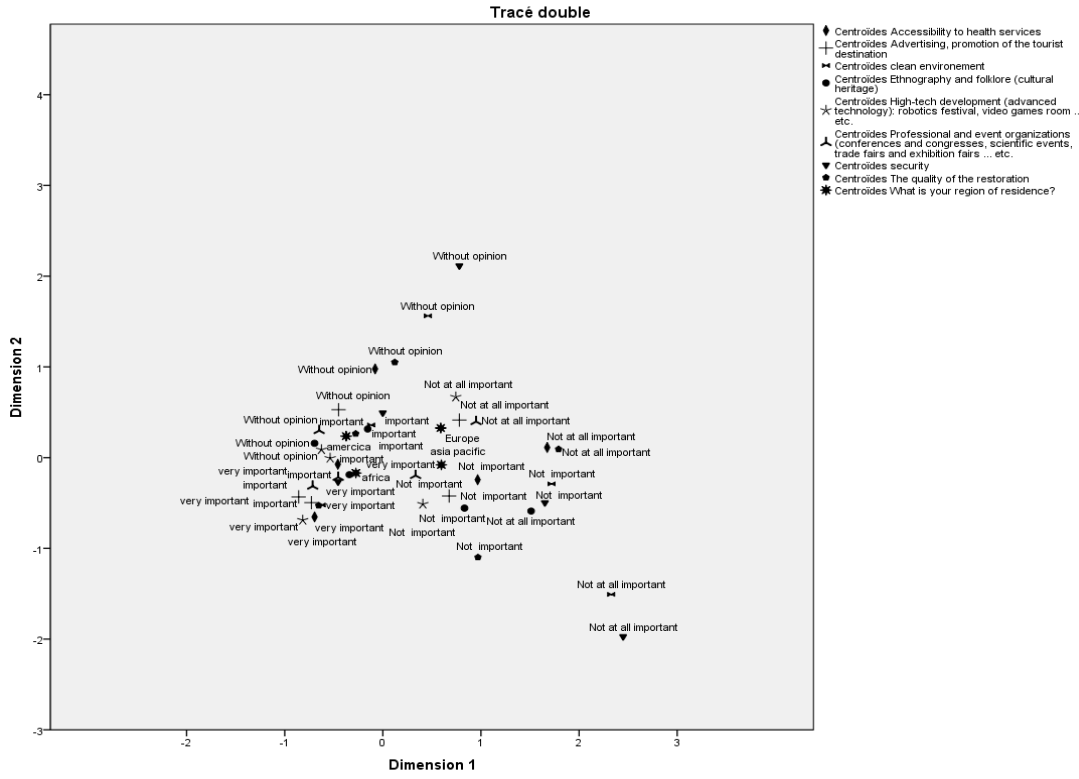

Source: Authors, processing in the Spss software

\section{Discussion}

The results of this research highlight the significant influence of personal factors on the tourists' perception, exposing the limitations of standard methods used to define the general interests and needs of tourists. Currently, these methods are subject to criticism (Mckercher, 2016). In the tourism industry, the survey of consumer habits and opinions is of particular importance. Travelers are heterogeneous in their composition, with different preferences and dislikes. Therefore, to satisfy their requests and build their loyalty, it is necessary to decipher the content of their potential demand, to understand it, and then to transform it into actual demand.

The significant averages of the study groups were compared to each other (Appendix B: Tables 12, 13, 14 and 15). This allowed to obtain a clearer picture of the expectations of the different tourist groups according to their age, gender, motivation and geographical region of origin.

Based on the results obtained, four hierarchical models were created. Each model classifies and categorizes the attractions into three groups in order of importance. This was done according to: gender, age, motivation and geographical origin.

In the ranking of attractions, it can be seen that male and female tourists attach different importance to certain attractions. The difference between men and women is significant for anthropology and folklore, public places, shopping resources, nightlife and the diversity of means of transport.

Men attach a significant importance to public spaces (gardens, squares, etc.), they are ranked as the 3rd most important attraction. Contrary to women, who rank this attraction in 8th position (Tables 12, Appendix B). This data is in line with that obtained by Carr (2001), which explains that this difference in judgement is due to the perception of danger. The author observed that men were more likely than women to perceive virtually no or low levels of danger in public spaces. Men, in contrast to women, also attach great importance to the variable "nightlife". 
JOURNAL OF TOURISM AND SERVICES

Issue 20, volume 11, ISSN 1804-5650 (Online)

www.jots.cz

Graph 10.Gender, hierarchical models

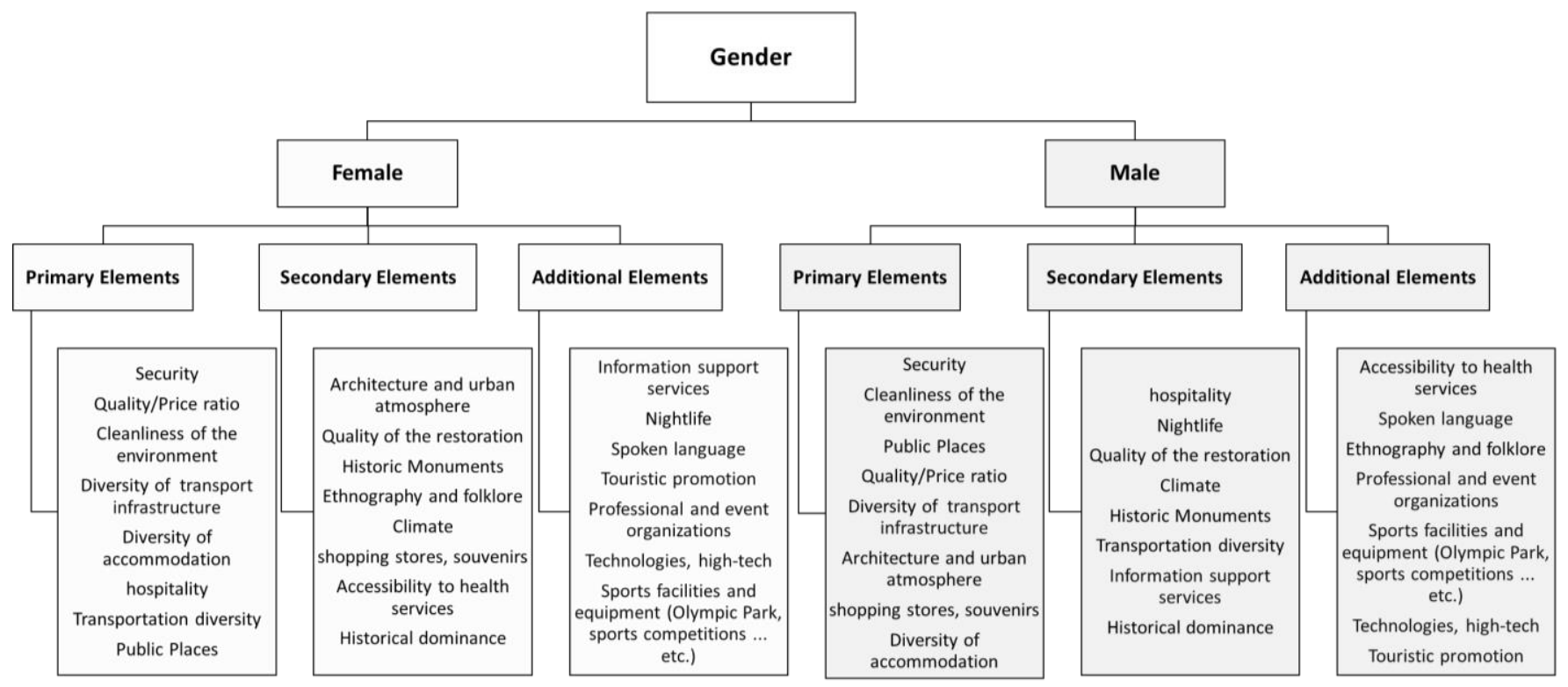

Source: Authors, based on the results obtained

Indeed, according to Giordano \& al. (2018), urban nightlife tourist activities (clubs, bars, pubs and discotheques casino, etc.) are mainly frequented by young men rather than young women. This could still be related to the perception of danger. Women, for their part, attach great importance to ethnography and folklore. They are more likely to be motivated by cultural reasons. These results support our hypothesis that gender has a significant effect on the tourists' perception.

"Grap 11" shows that the preferences of visitors belonging to the G1, G2, G4 and G3, in terms of tourist attractions do not differ much according to their age. Spearman Rho's values (Appendix B, Table 13), are 0.8044 for the correlation between G1 \& G2, 0.786 for G1 \& G3 and 0.7906 for G1 \& G4. These values indicate a considerable correlation between the variables.

However, there appears to be a significant difference between the other groups. On the basis of the results obtained, it is clear that the perception of adolescents (G1) (under 18 years of age) and older people (50-65 years of age) (G5) is not the same (Table 13, Appendix B). The perception of older people (G5) regarding value for money (4.09), diversity of tourist accommodation (4.00), historical monuments, world heritage (4.00) and public spaces (4.00) is easier to estimate. These attractions were rated to better by older people (G5) than by teenagers (G1).

The senior market is very specific (G5). Travellers over the age of 50 are motivated by the need to renew their social life, hence their desire to visit public spaces, which are meeting places and where it is easier to socialize with other people. They also pursue learning and the acquisition of cognitive knowledge, to this end they attempt to move more towards cultural and heritage attractions, which are indeed a rich resource for education. These results are in line with the findings of M.C. Sellick (2004) cited by Habil \& al (2012).

Compared to this group of senior, travelers under the age of 18 placed more importance on the following attractions: friendliness of inhabitants, shopping opportunities, health information services and assistance. This may be related to their state of mind, their apprehension about travelling and settling in another country, a destination they may not know and the need for reassurance about their health or even access to information. 
JOURNAL OF TOURISM AND SERVICES

Issue 20, volume 11, ISSN 1804-5650 (Online)

www.jots.cz

Graph 11. Age, hierarchical models.

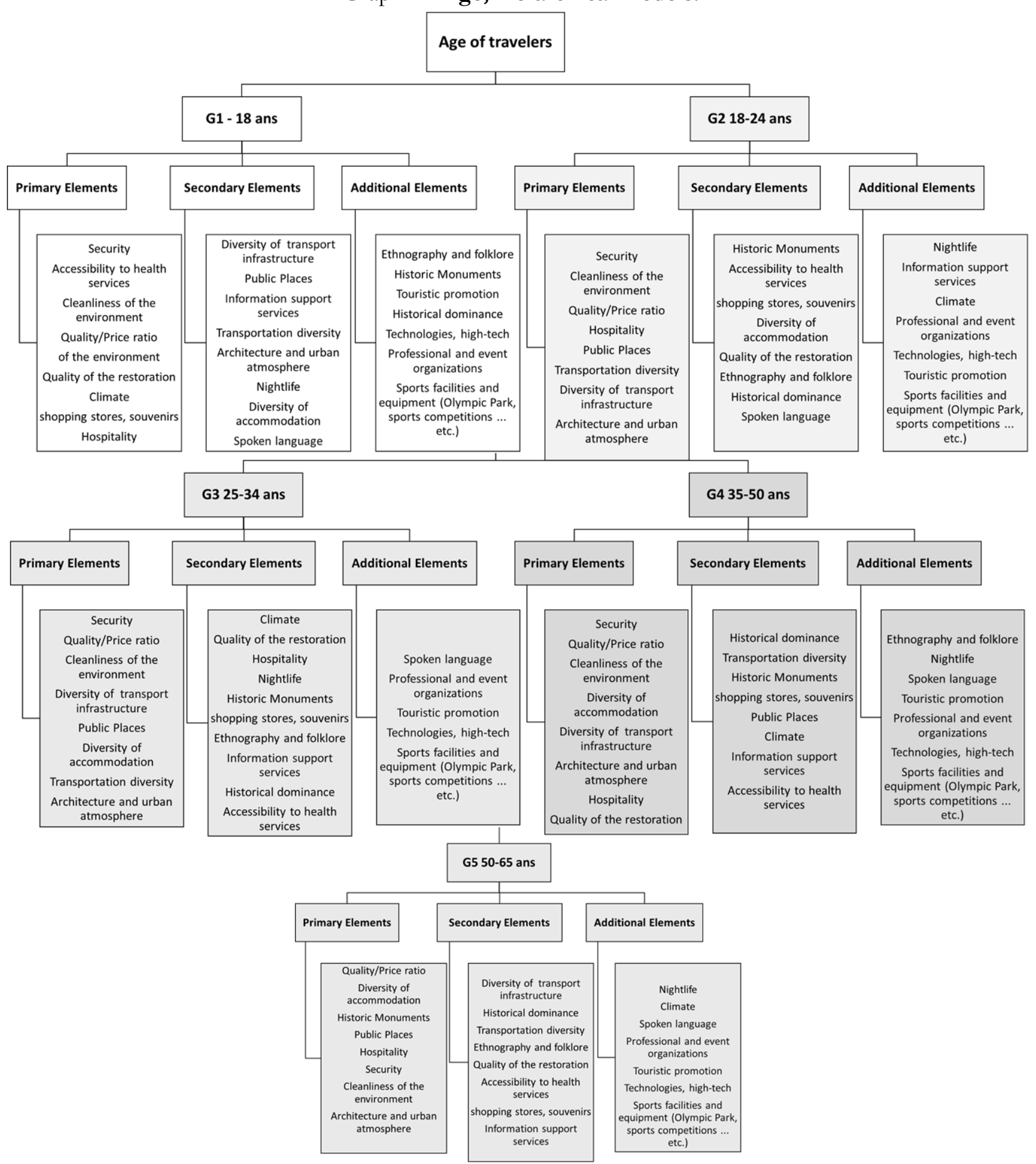

Source: Authors, based on the results obtained

Travelers under the age of 18 also place greater importance on language. The under-18s consider this variable to be important $(3,625)$ and is ranked 11 th by this group. Not speaking the language of the host community can be a barrier, and depending on the results, this barrier is more critical for this group of travelers. Currently, there are no references in the scientific literature to support the results obtained for this age group (- 18 years). It should be pointed out that in the field of tourism, childhood is a very absent subject of study (Dallari \& Mariotti, 2016). 


\section{JOURNAL OF TOURISM AND SERVICES}

Issue 20, volume 11, ISSN 1804-5650 (Online)

www.jots.cz

Thus, this data is an asset, which helps us to better understand the expectations of this group of people. It is important to note that in tourism marketing, if the target is the family, it is crucial to understand the demand of teenagers, because they actively participate in the decision-making process and significantly influence the final purchase decision. Parents are only satisfied if their child is happy (Niemczyk, 2015). Cited by Jelínková \& al (2017).

Unlike teenagers, travelers in the age groups (G2), (G3), (G4) and senior (G5) share many opinions. With regard to architecture and urban atmosphere, historical monuments, transportation infrastructure, and housing diversity, these elements are more valuable and were ranked higher by these groups than by adolescents. In particular, for senior citizens, the results show that immersion in the way of life of the inhabitants is perceived as an essential attraction, an important value is given by this group of tourists to public spaces, which are the beating heart of the cities, favorable meeting places

(4.00).

As far as the safety variable is concerned, it is considered an important element for all groups of travelers of all ages. Safety is judged by the first four age groups as the attraction with the highest score. For the elderly, it is in 6th place, just after reception and public places, with a score of (3.82). In fact, these results are in line with those established by previous work, which concludes that safety plays an important role in tourism and travel (Williams \& Baláž, 2015).

\section{Graph 12.Motivation, hierarchical models}

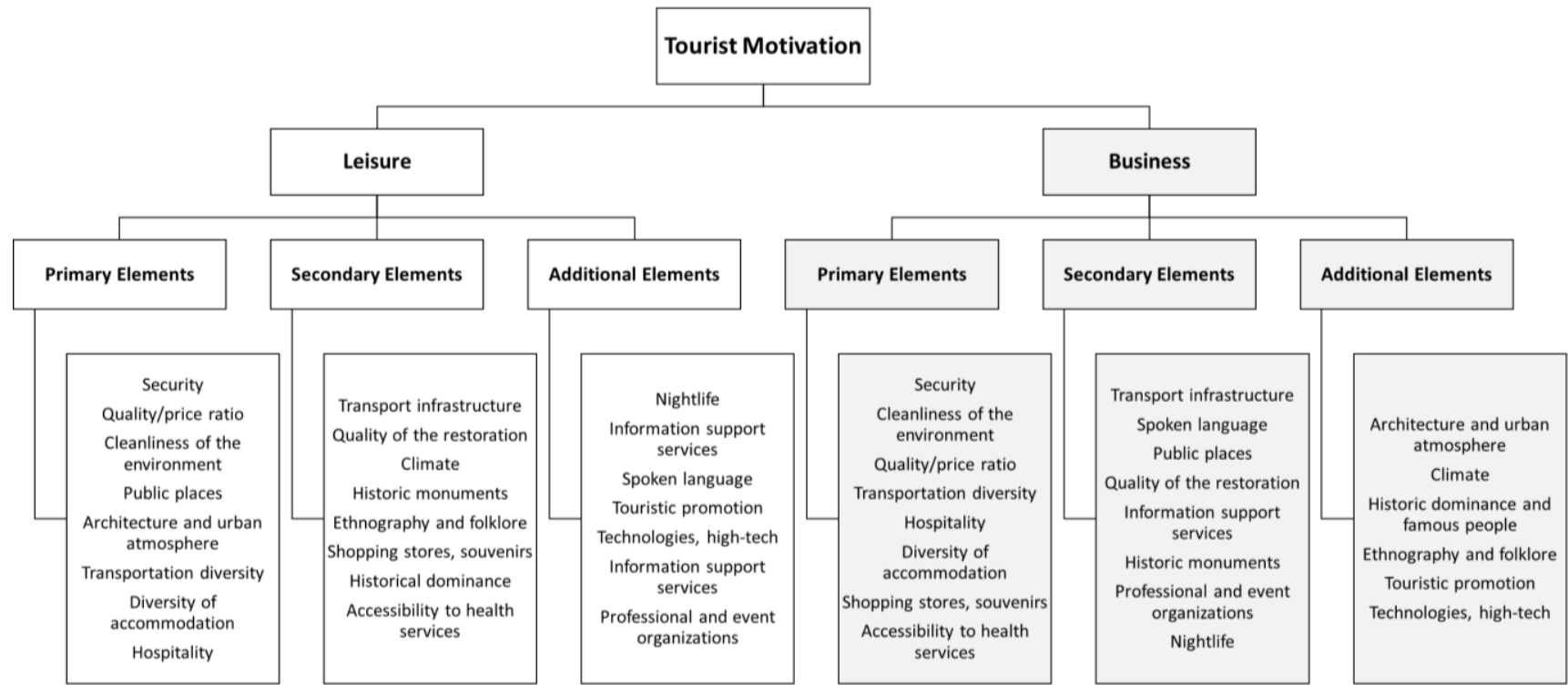

Source: Authors, based on the results obtained

"Graph 12" shows for the first group of travelers, whose purpose of the visit was motivated by leisure, safety, price, clean environment, public squares, architecture and urban atmosphere, transport diversity, accommodation diversity and hospitality, were ranked as the six most important attractions influencing the tourist attractiveness of cities. Sports facilities, professional organizations (congresses, trade fairs, etc.), high technology, tourism promotion and the language spoken by the inhabitants are considered by this group of tourists as the six attractions with the least influence on the attractiveness of the destination.

For the group of tourists whose travel was stimulated by business (conferences, professional training courses, etc.), the best rating was given to safety, followed successively by cleanliness of the environment, value for money, diversity of transport, hospitality of the inhabitants, and in sixth place the varied choice of accommodation. As for the six attractions, considered the least important by this group 


\section{JOURNAL OF TOURISM AND SERVICES}

Issue 20, volume 11, ISSN 1804-5650 (Online)

www.jots.cz

of travelers, they include sports facilities and equipment, advanced technology, tourist promotion, ethnography and folklore, historical dominance and climate.

Between the two groups, the judgment of professional organizations is a point of disagreement, for a business traveler, this attraction is fairly well appreciated (3.45). In contrast to the evaluation given by a leisure tourist, who ranks it among the last, with a score of (2.40). The purpose of the trip explains this difference.

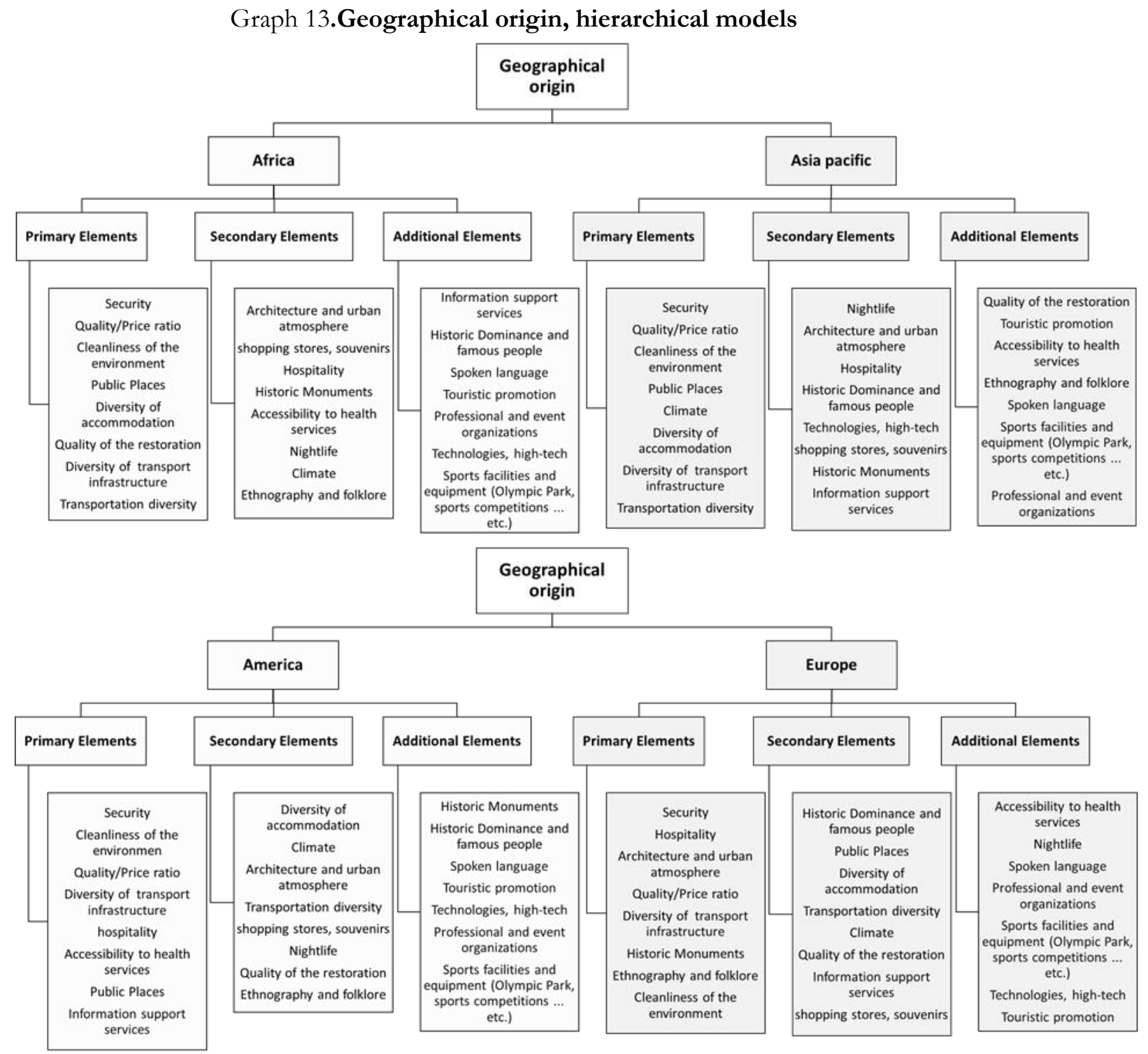

Source: Authors, based on the results obtained

However, the difference is more pronounced in the perception of cultural and historical attributes. Such as architecture and urban atmosphere, rated (3.83), public spaces (3.86), folklore (3.53), in the case of leisure travel experiences. In the case of business travel, these elements are less well estimated (3.33), (3.55) and (3.09). These results are consistent with the findings of several authors, who recognize that culture is one of the incentives for tourists to visit cities (Ritchie \& Zins, 1998; Karski 1990; Mottura, 1994; Cattle, 2019).

The results show the variation in the importance given by the two groups of travelers to different motivations (Table 14, Appendix B). Pearson's correlation coefficient (Spearman's rho $=0.7581$ ) reveals 


\section{JOURNAL OF TOURISM AND SERVICES}

Issue 20, volume 11, ISSN 1804-5650 (Online)

www.jots.cz

a median correlation between the two series (Leisure / Business), illustrating the influence of motivation on a tourist's judgement of the importance of attractions. Out of 23 attributes, visitors agreed on only two elements. This discrepancy contributes to the validation of the fir the third hypothesis.

In terms of geographical origin, the hierarchical model (Graph 13), based on (Table 15, see Appendix B), clearly illustrates the differences in the perceptions of tourists from different geographical origins regarding tourist attractions. These results support those of (Mayo \& Jarvis, 1981; Chen \& Kerstetter, 1999) on the fact that geographical origin has an impact on the tourists' perception. "Graph 13" shows that the Asia-Pacific traveler group, unlike other groups, places a high importance on technological advances, giving a score (3.16). This same group also considers climate as a major attraction. Europeans, on the other hand, place architecture and urban atmosphere in 3rd place and historical monuments in 6th place, judged as main attractions. However, the other groups of travelers consider these attractions more as secondary attractions.

\section{Conclusion}

The results of this study have theoretical and practical implications. Firstly, on a theoretical level, this study supports previous studies carried out to understand the influence of internal factors on tourism perception (Goodrich, 1978; Chen \& Kerstetter, 1999; Baloglu \& McCleary, 1999; Das\& al., 2007; Neethiahnanthan \& al.; 2014). Consequently, it contributes to advancing existing knowledge on the subject, and to consolidating the body of literature. The models proposed at the outcome of this research contribute to the theory of tourist attractions by explaining the form that Leiper's "primary" and "secondary" attractions can take, in an urban tourism context, while focusing on the tourist as the center of the study.

The second implication of this paper, is a managerial involvement. A destination cannot expect to accommodate all types of visitors. Once the tourism benefits of a destination have been defined, it is the responsibility of managers to establish marketing strategies, where they target the people most susceptible to be attracted, interested, by the offer proposed by the destination (Rithcie \& Crouch, 2005). The proposed models therefore represent a support that managers could eventually consult to understand the "primary, secondary and complementary" tourism demand of different segments. Thus, target the most favourable market, towards which they will communicate and market their product.

It can be noticed that safety, money value and accessibility represent a generic interest. These attractions are perceived as important, by the integrity of the travelers, regardless of age, gender, motivation or origin. However, a positive influence of internal factors on tourism perception is observed. Thus, the models provide a good perspective on the divergence of perceptions, and confirm the need for market segmentation in the development of product strategy. These models can be used as a reference, a decision support tool, as it helps to better identify and understand the sub-groups that make up the broad traveling public. This will allow decision-makers to precisely reach consumers with diverse needs and interests.

The limitations of this study are related principally to the size of the study sample, which is relatively small. This however, does not in any way affect its validity since the parameters related to it, assert its representativeness. Therefore, it is felt that more in-depth future research, with a larger and representative sample that covers different age groups, for different regions of origin as well as for different motivations, and gender, is required to increase reliability and increase external validity.

This research examined the influence of personal factors of a socio-demographic nature on the perception of tourists. This approach is one of the most commonly used marketing approaches to segment tourism markets. However, to complete this study, it is recommended that more sophisticated research be conducted that focuses on the study of the influence of psychological factors on the 


\section{JOURNAL OF TOURISM AND SERVICES}

Issue 20, volume 11, ISSN 1804-5650 (Online)

www.jots.cz

perception of tourists. Combining the results of the two studies will help marketers better predict behavior in order to communicate more effectively with potential consumers.

\section{Acknowledgements}

This research paper has been elaborated with the support of Direction Générale de la Recherche Scientifique et du Developpement Technologique (DGRSDT)

\section{References}

1. Androniceanu, A., Gherghina, R. \& Ciobanasu, M. (2019). The interdependence between fiscal public policies and tax evasion. Administratie si Management Public, 32, 32-41.

2. Ashworth, G. (2012). Do we Understand Urban Tourism? Journal of Tourism \& Hospitality 01.

3. Ashworth, G., and Page, S.J. (2011). Urban tourism research: Recent progress and current paradoxes. Tourism Management 32, 1-15.

4. Baloglu, S. and McCleary, W. K. (1999). U.S. international pleasure travelers' images of four Mediterranean destinations: a comparison of visitors and non-visitors, Journal of Travel and Tourism Research, 8(2), 144-151.

5. Beerli, A., \& Martín, J. D. (2004b). Tourists' characteristics and the perceived image of tourist destinations: a quantitative analysis-A case study of Lanzarote, Spain. Tourism Management, 25 (5), 623-636.

6. Beerli, A., and Martín, J.D. (2004). Factors influencing destination image. Annals of Tourism Research 31, 657-681.

7. Boivin, M., and Tanguay, G.A. (2019). Analysis of the determinants of urban tourism attractiveness: The case of Québec City and Bordeaux. Journal of Destination Marketing \& Management 11, 67-79.

8. Botti, L., Peypoch, N., and Solonandrasana, B. (2008). Time and tourism attraction. Tourism Management 29, 594-596.

9. Boualem, K. (2007). La ville et le tourisme : relation ancienne, complexité nouvelle et défi conceptuel . Téoros, 26-3, pp.76-79.

10. Bramwell, B. (1998). User satisfaction and product development in urban tourism. Tourism Management 19, 35-47.

11. Buhalis, D. (2000). Marketing the competitive destination of the future. Tourism Management, 21, 97-116.

12. Carr, N. (2001). An exploratory study of gendered differences in young tourist's perception of danger within London. Tourism Management, 22(5):565-570.

13. CHAZEL F et al, (1970), L'analyse des processus sociaux, édition mouton.

14. Chen, P. J., \& Kerstetter, D. L. (1999). International students' image of rural Pennsylvania as a travel destination. Journal of Travel Research, 37, 256-266.

15. Clavé-Mercier, V. (2017). L'entrepreneurialisme urbain comme mode d'animation: l'espace public madrilène disputé. Ambiances.

16. Cocean, P. 1984, Potențialul economic al carstului în Munții Apuseni (Le potentiel économique du karst dans Les Montagnes Apuseni), Editura Academiei, București.

17. Dallari, F., and Mariotti, A. (2016). Les pratiques touristiques ciblées sur l'enfance: vers une nouvelle perspective ?: Des colonies de vacances au projet Seninter : l'expérience italienne. Via Tourism Review. 


\section{JOURNAL OF TOURISM AND SERVICES}

Issue 20, volume 11, ISSN 1804-5650 (Online)

www.jots.cz

18. DAVEZIES, L. (2004). Temps de production et temps de consommation : les nouveaux aménageurs des territoires? .Futuribles, 295.

19. Debadyuti, D. Pratap K J Mohapatra. (2007). Factors influencing the attractiveness of a tourist destination: a case study. Journal of Services Research, Volume 7, Number 1.

20. Decrop, A. (2006). Vacation decision making. Wallingford, UK: CABI-Publishing.

21. Decrop, A. (2011). Le touriste consommateur : un caméléon.... Mondes Du Tourisme 4-13.

22. Edwards, D., Griffin, T., and Hayllar, B. (2008). Urban Tourism Research. Annals of Tourism Research 35, 1032-1052.

23. Gearing, C. E., Swart, W. W., \& Var, T. (1974). Establishing a Measure of Touristic Attractiveness. Journal of Travel Research, 12(4), 1-8.

24. Giordano, E., Nofre Mateu, J., and Crozat, D. (2018). La touristification de la vie nocturne : une nouvelle frontière pour la recherche sur la nuit urbaine. Cybergeo.

25. Goodrich, J.N. (1978). The Relationship Between Preferences for and Perceptions of Vacation Destinations: Application of a Choice Model. Journal of Travel Research 17, 8-13.

26. Grundey, D., Vilutyte, G. (2012). Development of the tourism sector in Lithuania: a focus on the 50+ sector. Journal of International Studies, Vol. 5, No 1, 2012, pp. 30-37.

27. Gunn, C.A. (1979). Vacationscape: Designing Tourist Regions. New York: Van Nostrand Reinhold.

28. Hakeem, S. M. A., \& Khan, M. Y. (2018). Urban tourism: the perspective on tourism impacts in Cambridge, United Kingdom. Marketing and Management of Innovations, (3), 268-275. http://doi.org/10.21272/mmi.2018.3-24

29. Heung, V. C. S., \& Quf, H. (2000). Hong Kong as a travel destination: An analysis of Japanese tourists' satisfaction levels, and the likelihood of them recommending Hong Kong to others. Journal of Travel and Tourism Marketing, 9(1/2), 57-80.

30. Hong-bumm, K. (1998). Perceived attractiveness of korean destinations. Annals of Tourism Research 25, 340-361.

31. Horita, Y. (2018). Urban Development and Tourism in Japanese Cities. Tourism Planning \& Development 15, 26-39.

32. Iatu.,C \& Bulai ., M. (2011). New approach in evaluating tourism attractiveness in the region of Moldavia (Romania). International journal of energy and environment, Issue 2, Volume 5, 165174.

33. INGALLINA, P., PARK, J. (2005). City marketing est espaces de consommation : les nouveaux enjeux de l'attractivité urbaine. Revue urbanisme, 344, 64-67.

34. Jansen-Verbeke, M., Inner city tourism: resources, tourists and promoters. Annals of" Tourism Research 1986, 13(1), 79-100.

35. Jelínková, D., Tučková, Z., \& Jurigová, Z. (2017). Market segment of families with children: A new stimulus for modern Czech spa industry? Journal of International Studies, 10(2), 158-169.

36. Jenny, C., Lee, J., Tom, B. (2013). Tourism and souvenirs: glocal perspectives from the margins (Bristol: Channel View Publ).

37. Jordaan, Y., \& Prinsloo, M. (2001). Grasping service marketing. Pretoria Grapevine News

38. Kadri, B., and Pilette, D. (2017). Le tourisme métropolitain renouvelé (Québec: Presses de l'Université du Québec).

39. Karski, A. (1990). Urban Tourism: A Key to Urban Regeneration. The Planner, 6, 15-17.

40. Kim D., \& Perdue R. R. (2011). The influence of image on destination attractiveness. Journal of Travel \& Tourism Marketing, 28, 225-239.

41. Krešić D., \& Darko Prebežac, D. (2011). Index of destination attractiveness as a tool for destination attractiveness assessment. Original Scientific Papep, 59(4), 497-517.

42. Kearney, H., Kliestik, T., Kovacova, M., \& Vochozka, M. (2019). The Embedding of Smart Digital Technologies within Urban Infrastructures: Governance Networks, Real-Time Data 


\section{JOURNAL OF TOURISM AND SERVICES}

Issue 20, volume 11, ISSN 1804-5650 (Online)

www.jots.cz

Sustainability, and the Cognitive Internet of Things, Geopolitics, History, and International Relations, 11(1), 98-103.

43. Law, C.M. (1992). Urban Tourism and its Contribution to Economic Regeneration. Urban Studies 29, 599-618.

44. Leiper, N. (1990). Tourist attraction systems. Annals of Tourism Research 17, 367-384.

45. Lew, A.A. (1987). A framework of tourist attraction research. Annals of Tourism Research 14, 553-575.

46. Lin, C.-Y. (2018). Emerging challenges of an urban creative economy: reflections on the governance of creative clusters in Taipei City. European Planning Studies 26, 421-437.

47. Loganatan, N., Ahmad, N., Mursitama, T. N., Taha, R., Mardani, A., \& Streimikiene, D. (2019). The effects of exchange rate, price competitiveness indices and taxation on international tourism demand in Malaysia. Economics \& Sociology, 12(3), 86-97.

48. Lusticky, M., \& Kincl, T. (2012). Tourism Destination Benchmarking: Evaluation and Selection of the Benchmarking Partners. Journal of Competitiveness, 4(1), 99-116.

49. Marie,D., Boualem, K, Eric, L.L., Larbi, S. (2018). Risques, résilience et pérennité des destinations touristiques : une introduction. Études caribéennes [Online].

50. Mayo, E., \& Jarvis, L. (1981). Psychology of leisure travel. Boston: CABI Publishing.

51. McKercher, B. (2017). Do Attractions Attract Tourists? A Framework to Assess the Importance of Attractions in Driving Demand: Do Attractions Attract Tourists? International Journal of Tourism Research 19, 120-125.

52. Mottura, P. (1994). Espaces tourisme \& loisirs. In cahier Espaces n ${ }^{\circ} 37$.

53. Oakley, K. (2016). Whose creative economy? Inequality and the need for international approaches. Les Enjeux de l'information et de la communication $\mathrm{N}^{\circ} 17 / 2,163$.

54. Ohanyan G., Androniceanu, A. (2017). Evaluation of IMF program effects on employment in the EU, Acta Oeconomica, 67(3), 311-332.

55. Page, S. (2015). Tourism management (Fifth edition). Routledge.

56. Pearce, D.G. (2001). An integrative framework for urban tourism research. Annals of Tourism Research 28, 926-946.

57. Ragavan, N.A., Subramonian, H., and Sharif, S.P. (2014). Tourists' Perceptions of Destination Travel Attributes: An Application to International Tourists to Kuala Lumpur. Procedia - Social and Behavioral Sciences 144, 403-411.

58. Rajesh R. (2013). Impact of Tourist Perceptions, Destination Image and Tourist Satisfaction on Destination Loyalty: A Conceptual Model. Vol. 11 No 3. Special Issue. págs. 67-78.

59. Rasoolimanesh, S.M., M. Jaafar, A. Marzuki and S. Abdullah (2019). Examining the effects of personal factors and travel characteristics on tourists' perceived crowding. European Journal of Tourism Research 22, pp. 5-19

60. Reda, K.M. (2018). La résilience organisationnelle comme outil de relance d'une destination. Le cas du Québec. Études Caribéennes.

61. Richards, G., and Wilson, J. (2006). Developing creativity in tourist experiences: A solution to the serial reproduction of culture? Tourism Management 27, 1209-1223.

62. Ritchie, J. R. B., \& Crouch, G. I. (2011). The competitive destination: A sustainable tourism perspective. CABI Publ.

63. Ritchie, J.R.B., and Zins, M. (1978). Culture as determinant of the attractiveness of a tourism region. Annals of Tourism Research 5, 252-267.

64. Salama, A., Oláh, J. (2019). Key factors affecting unemployment in the Arab world. Central European Journal of Labour Law and Personnel Management, 2 (2), 60-72. doi: 10.33382/cejllpm.2019.03.05 


\section{JOURNAL OF TOURISM AND SERVICES}

Issue 20, volume 11, ISSN 1804-5650 (Online)

www.jots.cz

65. Serkan, B., Volkan, A. (2008). Visitors' perception of a tourism destination: the case of pamukkale. : an international multidisciplinary journal of tourism. Volume 8, Number 1, Spring 2013, pp. 115-132.

66. Terrin, J.-J. (2014). Le projet du projet: concevoir la ville contemporaine (Marseille: Parenthèses).

67. TERZIBASOGLU.,E. (2015). Réinventer le tourisme urbain. 4e SOMMET MONDIAL SUR LE TOURISME URBAIN. 14-15 Marrakech (Maroc).

68. Vengesayi, S. (2003). A conceptual model of tourism destination competitiveness and attractiveness, ANZMAC Conference Proceedings, 637-647.

69. Williams, A.M., and Baláž, V. (2015). Tourism Risk and Uncertainty: Theoretical Reflections. Journal of Travel Research 54, 271-287.

70. Yangzhou Hu, and Ritchie, J.R.B. (1993). Measuring Destination Attractiveness: A Contextual Approach. Journal of Travel Research 32, 25-34.

\section{Brief description of Author/Authors:}

\section{Amina CHEBLI}

$\mathrm{PhD}$ student at the Ecole Polytechnique d'Architecture et Urbanisme d'Alger (EPAU). Algiers, Algeria. Affiliated to Ville, Urbanisme et development durable, laboratory (VUDD). Web: http://www.epaualger.edu.dz/index.php/component/content/featured?id=featured\&limit=8\&start=168 Email address: a.chebli@epau-alger.edu.dz Architect, a graduate of a master's degree in Urban Planning from Badji Mokhtar University. Department of Architecture, Annaba Algeria. Research Fields: urban tourism, tourism management, tourist attractiveness, and decision support tool.

\section{Meriem Chabou Othmani}

Architect-engineer, Professor at the Ecole Polytechnique d'Architecture et Urbanisme d'Alger (EPAU). Algiers, Algeria. Email address: m.chabou@epau-alger.edu.dz. Doctorate in Architecture and Urbanism (obtained as an equivalence to the doctorate from the TU-Berlin) Fakultät VII Architecture

Environment Society - Technical University of Berlin, Germany. Research Fields: urban requalification, urban management, urban policies, and land planning.

\section{Foued Ben Said}

Member of the Research unity of Applied Econometrics in Finance; Tunis el Manar University. Associate-professor of statistics and Data analysis, department of Quantitative Methods, High School of Business, Manouba University, Tunisia. Web: https://bensaidfoued.wordpress.com/ E-mail: fdbs71@yahoo.fr; foued.bensaid@esct.uma.tn. Graduated in Applied statistics, Applied Econometrics and Quantitative and Qualitative Data Analysis. He has a PhD in Economic Sciences 2012. Research Fields: applied statistics, Applied Spatial Econometric, Quantitative and Qualitative data analysis; strategic analysis. 


\section{Appendix A.}

\section{Survey on urban tourism, determination of tourist attractions in urban destinations}

As part of research project, we are required to prepare a study on the theme "the tourist attractiveness of urban destinations", please take a few moments of your time, to help us and contribute to this research by answering our anonymous questionnaire. Thank you.

\section{Section A. Personal details}

A. What age group do you belong to? *

Under 18 years

18 years 24 years

25 years 34 years

35 years 49 years

50 years 64 years

Over 65 years

B. What is your gender? *

Male

Female

C. What is your education level ?*

Primary school

middle school

High School

University

higher education

D. What is your region of residence? *

Africa

Asia Pacific

America

Europe

E. During this last period you made a tourist trip to a city. Please indicate the purpose of your trip?

Leisure

Business tripe (conference, internships, scholarship...etc.)

\section{Section 2. Evaluation of Tourist attractions}

While preparing your trip, whether it is leisure or business, what were the attractions (list of items below) that influenced your perception and that you considered (important / less important) when making your decision

\begin{tabular}{|l|l|l|l|l|l|}
\hline Attractions & $\begin{array}{l}\text { Not at all } \\
\text { important }\end{array}$ & $\begin{array}{l}\text { Not } \\
\text { important }\end{array}$ & $\begin{array}{l}\text { Without } \\
\text { opinion }\end{array}$ & Important & Very \\
Important
\end{tabular}


JOURNAL OF TOURISM AND SERVICES

Issue 20, volume 11, ISSN 1804-5650 (Online)

www.jots.cz

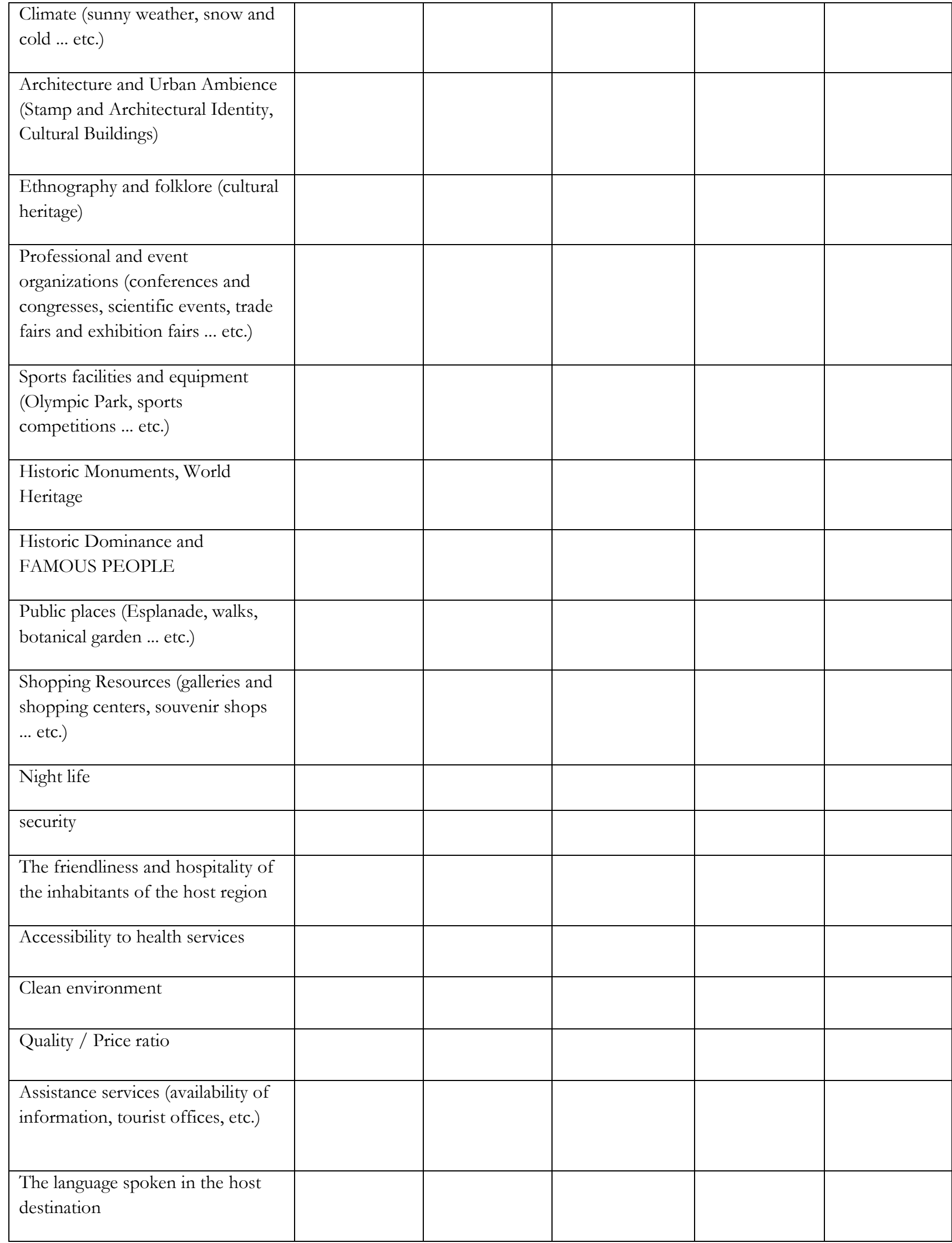




\section{JOURNAL OF TOURISM AND SERVICES}

Issue 20, volume 11, ISSN 1804-5650 (Online)

www.jots.cz

\begin{tabular}{|l|l|l|l|l|l|}
\hline $\begin{array}{l}\text { Transport infrastructure (airport } \\
\text { terminal, seaport, etc.) and easy } \\
\text { access to the tourist destination } \\
\text { (Visa, distance) }\end{array}$ & & & & & \\
\hline Transportation Diversity & & & & & \\
\hline $\begin{array}{l}\text { Diversity of tourist } \\
\text { accommodation }\end{array}$ & & & & & \\
\hline $\begin{array}{l}\text { The quality of the restoration } \\
\text { High-tech development (advanced } \\
\text { technology): robotics festival, } \\
\text { video games room ... etc. }\end{array}$ & & & & & \\
\hline $\begin{array}{l}\text { Advertising, promotion of the } \\
\text { tourist destination }\end{array}$ & & & & & \\
\hline
\end{tabular}

\section{Appendix B}

Table 11. Levene's test results for gender

\begin{tabular}{|l|l|l|l|l|l|l|}
\cline { 3 - 7 } \multicolumn{2}{c|}{} & F & Sig. & t & df & $\begin{array}{l}\text { Sig. (2- } \\
\text { tailed) }\end{array}$ \\
\hline \multirow{2}{*}{ Climate } & Equal variances assumed & .151 & .698 & -.688 & 169 & .493 \\
\cline { 2 - 8 } & Equal variances not assumed & & & -.685 & 71.843 & .495 \\
\hline $\begin{array}{l}\text { Architecture and } \\
\text { Urban Ambience }\end{array}$ & Equal variances assumed & 5.544 & .020 & -1.052 & 169 & .294 \\
\cline { 2 - 8 } & Equal variances not assumed & & & -.971 & 63.638 & .335 \\
\hline $\begin{array}{l}\text { Ethnography and } \\
\text { folklore (cultural } \\
\text { heritage) }\end{array}$ & Equal variances assumed & .030 & .863 & -2.433 & 169 & .016 \\
\cline { 2 - 8 } & Equal variances not assumed & & & -2.411 & 71.139 & .018 \\
\hline $\begin{array}{l}\text { Professional and } \\
\text { event organizations }\end{array}$ & Equal variances assumed & 1.158 & .283 & 1.638 & 169 & .103 \\
\cline { 2 - 8 } & Equal variances not assumed & & & 1.560 & 66.725 & .124 \\
\hline $\begin{array}{l}\text { Sports facilities and } \\
\text { equipment }\end{array}$ & Equal variances assumed & 4.352 & .038 & 3.214 & 169 & .002 \\
\cline { 2 - 8 } & Equal variances not assumed & & & 2.956 & 63.355 & .004 \\
\hline $\begin{array}{l}\text { Historic } \\
\text { Monuments. World } \\
\text { Heritage }\end{array}$ & Equal variances assumed & 3.194 & .076 & -1.062 & 169 & .290 \\
\cline { 2 - 8 } & Equal variances not assumed & & & -.978 & 63.446 & .332 \\
\hline & Equal variances assumed & .499 & .481 & -1.135 & 169 & .258 \\
\hline
\end{tabular}




\section{JOURNAL OF TOURISM AND SERVICES}

Issue 20, volume 11, ISSN 1804-5650 (Online)

www.jots.cz

\begin{tabular}{|c|c|c|c|c|c|c|}
\hline $\begin{array}{l}\text { Historic } \\
\text { Dominance and } \\
\text { Famous People }\end{array}$ & Equal variances not assumed & & & -1.096 & 68.195 & .277 \\
\hline \multirow[t]{2}{*}{ Public places } & Equal variances assumed & 2.183 & .141 & .086 & 169 & .931 \\
\hline & Equal variances not assumed & & & .080 & 63.840 & .937 \\
\hline \multirow{2}{*}{$\begin{array}{l}\text { Shopping } \\
\text { Resources }\end{array}$} & Equal variances assumed & .210 & .647 & .336 & 169 & .737 \\
\hline & Equal variances not assumed & & & .352 & 78.309 & .726 \\
\hline \multirow[t]{2}{*}{ Night life } & Equal variances assumed & .183 & .669 & .668 & 169 & .505 \\
\hline & Equal variances not assumed & & & .644 & 68.011 & .522 \\
\hline \multirow[t]{2}{*}{ Security } & Equal variances assumed & 2.518 & .114 & -1.490 & 169 & .138 \\
\hline & Equal variances not assumed & & & -1.314 & 59.830 & .194 \\
\hline \multirow{2}{*}{$\begin{array}{l}\text { Friendliness and } \\
\text { hospitality }\end{array}$} & Equal variances assumed & 3.609 & .059 & -1.620 & 169 & .107 \\
\hline & Equal variances not assumed & & & -1.505 & 64.326 & .137 \\
\hline \multirow{2}{*}{$\begin{array}{l}\text { Accessibility to } \\
\text { health services }\end{array}$} & Equal variances assumed & .417 & .519 & -1.358 & 169 & .176 \\
\hline & Equal variances not assumed & & & -1.377 & 74.064 & .173 \\
\hline \multirow[t]{2}{*}{ Clean environment } & Equal variances assumed & 2.386 & .124 & -.515 & 169 & .607 \\
\hline & Equal variances not assumed & & & -.480 & 64.589 & .633 \\
\hline \multirow{2}{*}{$\begin{array}{l}\text { Quality / Price } \\
\text { ratio }\end{array}$} & Equal variances assumed & 2.412 & .122 & -1.949 & 169 & .053 \\
\hline & Equal variances not assumed & & & -1.834 & 65.529 & .071 \\
\hline \multirow[t]{2}{*}{ Assistance services } & Equal variances assumed & .260 & .611 & -.582 & 169 & .561 \\
\hline & Equal variances not assumed & & & -.570 & 69.753 & .570 \\
\hline \multirow{2}{*}{$\begin{array}{l}\text { The language } \\
\text { spoken in the host } \\
\text { destination }\end{array}$} & Equal variances assumed & 1.361 & .245 & .464 & 169 & .643 \\
\hline & Equal variances not assumed & & & .451 & 68.907 & .654 \\
\hline \multirow{2}{*}{$\begin{array}{l}\text { Transport } \\
\text { infrastructure }\end{array}$} & Equal variances assumed & 2.366 & .126 & -.846 & 169 & .399 \\
\hline & Equal variances not assumed & & & -.796 & 65.435 & .429 \\
\hline \multirow{2}{*}{$\begin{array}{l}\text { Transportation } \\
\text { Diversity }\end{array}$} & Equal variances assumed & 2.887 & .091 & -2.147 & 169 & .033 \\
\hline & Equal variances not assumed & & & -2.031 & 66.066 & .046 \\
\hline \multirow{2}{*}{$\begin{array}{l}\text { Diversity of tourist } \\
\text { accommodation }\end{array}$} & Equal variances assumed & 4.060 & .045 & -1.601 & 169 & .111 \\
\hline & Equal variances not assumed & & & -1.478 & 63.694 & .144 \\
\hline \multirow{3}{*}{$\begin{array}{l}\text { The quality of the } \\
\text { restoration }\end{array}$} & Equal variances assumed & .047 & .828 & -1.330 & 169 & .185 \\
\hline & Equal variances not assumed & & & -1.336 & 72.801 & .186 \\
\hline & Equal variances assumed & 1.985 & .161 & 1.393 & 169 & .165 \\
\hline
\end{tabular}




\section{JOURNAL OF TOURISM AND SERVICES}

Issue 20, volume 11, ISSN 1804-5650 (Online)

www.jots.cz

\begin{tabular}{|l|l|l|l|l|l|l|}
\hline $\begin{array}{l}\text { High-tech } \\
\text { development }\end{array}$ & Equal variances not assumed & & & 1.455 & 78.241 & .150 \\
\hline $\begin{array}{l}\text { Advertising, } \\
\text { promotion of the } \\
\text { tourist destination }\end{array}$ & Equal variances assumed & 1.219 & .271 & -.190 & 169 & .849 \\
\cline { 2 - 8 } & Equal variances not assumed & & & -.201 & 79.626 & .841 \\
\hline
\end{tabular}

Source: Authors, processing in the Spss software

Table 12. Ranking variables: gender

\begin{tabular}{|c|c|c|c|c|}
\hline What is your gender? * & Male (G1) & ranking & Female (G2) & ranking \\
\hline Climate (sunny weather, snow and cold. etc.) & 3.3953 & 12 & 3.5469 & 13 \\
\hline $\begin{array}{l}\text { Architecture and Urban Ambience (Stamp and } \\
\text { Architectural Identity, Cultural Buildings) }\end{array}$ & 3.5814 & 6 & 3.7891 & 9 \\
\hline Ethnography and folklore (cultural heritage) & 3.0698 & 19 & 3.5703 & 12 \\
\hline $\begin{array}{l}\text { Professional and event organizations (conferences and } \\
\text { congresses, scientific events, trade fairs and exhibition } \\
\text { fairs, ...etc. }\end{array}$ & 2.8605 & 20 & 2.5156 & 21 \\
\hline $\begin{array}{l}\text { Sports facilities and equipment (Olympic Park, sports } \\
\text { competitions, etc.) }\end{array}$ & 2.7907 & 21 & 2.1563 & 23 \\
\hline Historic Monuments, World Heritage & 3.3953 & 13 & 3.6250 & 11 \\
\hline Historic Dominance and FAMOUS PEOPLE & 3.2093 & 16 & 3.4531 & 16 \\
\hline Public places (Esplanade, walks, botanical garden, etc.) & 3.8140 & 3 & 3.7969 & 8 \\
\hline $\begin{array}{l}\text { Shopping Resources (galleries and shopping centers, } \\
\text { souvenir shops ...etc.) }\end{array}$ & 3.5814 & 7 & 3.5078 & 14 \\
\hline Night life & 3.4651 & 10 & 3.3125 & 18 \\
\hline Security & 4.0233 & 1 & 4.3047 & 1 \\
\hline $\begin{array}{l}\text { The friendliness and hospitality of the inhabitants of } \\
\text { the host region }\end{array}$ & 3.5116 & 9 & 3.8203 & 6 \\
\hline Accessibility to health services & 3.1860 & 17 & 3.4844 & 15 \\
\hline Clean environment & 3.9070 & 2 & 4.0078 & 3 \\
\hline Quality / Price ratio & 3.7674 & 4 & 4.1484 & 2 \\
\hline $\begin{array}{l}\text { Assistance services (availability of information, tourist } \\
\text { offices. etc.) }\end{array}$ & 3.2791 & 15 & 3.4063 & 17 \\
\hline The language spoken in the host destination & 3.1163 & 18 & 3.0078 & 19 \\
\hline $\begin{array}{l}\text { Transport infrastructure (airport terminal, seaport. } \\
\text { etc.) and easy access to the tourist destination (Visa, } \\
\text { distance) }\end{array}$ & 3.6977 & 5 & 3.8594 & 4 \\
\hline Transportation Diversity & 3.3953 & 14 & 3.8203 & 7 \\
\hline
\end{tabular}


JOURNAL OF TOURISM AND SERVICES

Issue 20, volume 11, ISSN 1804-5650 (Online)

www.jots.cz

\begin{tabular}{|l|l|l|l|l|}
\hline Diversity of tourist accommodation & 3.5349 & $\mathbf{8}$ & 3.8516 & $\mathbf{5}$ \\
\hline The quality of the restoration & 3.4186 & $\mathbf{1 1}$ & 3.7109 & $\mathbf{1 0}$ \\
\hline $\begin{array}{l}\text { High-tech development (advanced technology): } \\
\text { robotics festival, video games room, etc. }\end{array}$ & 2.7907 & $\mathbf{2 2}$ & 2.4844 & $\mathbf{2 2}$ \\
\hline Advertising. promotion of the tourist destination & 2.6512 & $\mathbf{2 3}$ & 2.6953 & $\mathbf{2 0}$ \\
\hline
\end{tabular}

Source: Authors, processing in the SPSS software

Rho Spearman Rank Order Correlation between: G1\&G2 $=0.8992$

Table 13.Ranking variables: Age

\begin{tabular}{|c|c|c|c|c|c|c|c|c|c|c|}
\hline $\begin{array}{l}\text { What age group do you } \\
\text { belong to? * }\end{array}$ & $\begin{array}{l}<18 \\
(\mathrm{G} 1)\end{array}$ & $\mathbf{R}$ & $\begin{array}{l}{[18 ; 25[} \\
(\mathrm{G} 2)\end{array}$ & $\mathbf{R}$ & $\begin{array}{l}{[25 ; 35[} \\
\text { (G3) }\end{array}$ & $\mathbf{R}$ & $\begin{array}{l}{[35 ; 50[} \\
(G 4)\end{array}$ & $\mathbf{R}$ & $\begin{array}{l}{[50 ; 65[} \\
(\mathrm{G} 5)\end{array}$ & $\mathbf{R}$ \\
\hline $\begin{array}{l}\text { Climate (sunny weather, } \\
\text { snow and cold. etc.) }\end{array}$ & 4.25 & 6 & 3.24 & 19 & 3.63 & 9 & 3.52 & 14 & 3.09 & 18 \\
\hline $\begin{array}{l}\text { Architecture and Urban } \\
\text { Ambience (Stamp and } \\
\text { Architectural Identity, } \\
\text { Cultural Buildings) }\end{array}$ & 3.88 & 13 & 3.73 & 8 & 3.75 & 8 & 3.69 & 6 & 3.82 & 8 \\
\hline $\begin{array}{l}\text { Ethnography and folklore } \\
\text { (cultural heritage) }\end{array}$ & 3.50 & 17 & 3.63 & 14 & 3.37 & 15 & 3.33 & 17 & 3.55 & 12 \\
\hline $\begin{array}{l}\text { Professional and event } \\
\text { organizations (conferences } \\
\text { and congresses, scientific } \\
\text { events, trade fairs and } \\
\text { exhibition fairs, ...etc. }\end{array}$ & 2.75 & 22 & 2.80 & 22 & 2.68 & 20 & 2.31 & 21 & 2.55 & 20 \\
\hline $\begin{array}{l}\text { Sports facilities and } \\
\text { equipment (Olympic Park, } \\
\text { sports competitions, etc.) }\end{array}$ & 2.63 & 23 & 2.12 & 23 & 2.51 & 23 & 2.19 & 23 & 2.18 & 23 \\
\hline $\begin{array}{l}\text { Historic Monuments, World } \\
\text { Heritage }\end{array}$ & 3.25 & 18 & 3.71 & 9 & 3.44 & 13 & 3.57 & 11 & 4.00 & 3 \\
\hline $\begin{array}{l}\text { Historic Dominance and } \\
\text { FAMOUS PEOPLE }\end{array}$ & 3.13 & 20 & 3.54 & 15 & 3.18 & 17 & 3.62 & 9 & 3.55 & 10 \\
\hline $\begin{array}{l}\text { Public places (Esplanade, } \\
\text { walks, botanical garden, etc.) }\end{array}$ & 4.13 & 10 & 3.88 & 5 & 3.85 & 5 & 3.52 & 13 & 4.00 & 4 \\
\hline $\begin{array}{l}\text { Shopping Resources (galleries } \\
\text { and shopping centers, } \\
\text { souvenir shops ...etc.) }\end{array}$ & 4.25 & 7 & 3.66 & 11 & 3.38 & 14 & 3.55 & 12 & 3.36 & 15 \\
\hline Night life & 3.88 & 14 & 3.41 & 17 & 3.50 & 12 & 3.02 & 18 & 3.27 & 17 \\
\hline Security & 5.00 & 1 & 4.32 & 1 & 4.19 & 1 & 4.19 & 1 & 3.82 & 6 \\
\hline $\begin{array}{l}\text { The friendliness and } \\
\text { hospitality of the inhabitants } \\
\text { of the host region }\end{array}$ & 4.25 & 8 & 4.07 & 4 & 3.51 & 11 & 3.67 & 7 & 3.91 & 5 \\
\hline
\end{tabular}




\section{JOURNAL OF TOURISM AND SERVICES}

Issue 20, volume 11, ISSN 1804-5650 (Online)

www.jots.cz

\begin{tabular}{|c|c|c|c|c|c|c|c|c|c|c|}
\hline $\begin{array}{l}\text { Accessibility to health } \\
\text { services }\end{array}$ & 4.75 & 2 & 3.68 & 10 & 3.13 & 18 & 3.36 & 16 & 3.45 & 14 \\
\hline Clean environment & 4.75 & 3 & 4.15 & 2 & 3.97 & 3 & 3.74 & 3 & 3.82 & 7 \\
\hline Quality / Price ratio & 4.75 & 4 & 4.12 & 3 & 4.00 & 2 & 3.95 & 2 & 4.09 & 1 \\
\hline $\begin{array}{l}\text { Assistance services } \\
\text { (availability of information, } \\
\text { tourist offices. etc.) }\end{array}$ & 4.00 & 11 & 3.39 & 18 & 3.24 & 16 & 3.50 & 15 & 3.27 & 16 \\
\hline $\begin{array}{l}\text { The language spoken in the } \\
\text { host destination }\end{array}$ & 3.63 & 16 & 3.44 & 16 & 2.85 & 19 & 2.90 & 19 & 2.82 & 19 \\
\hline $\begin{array}{l}\text { Transport infrastructure } \\
\text { (airport terminal, seaport. } \\
\text { etc.) and easy access to the } \\
\text { tourist destination (Visa, } \\
\text { distance) }\end{array}$ & 4.25 & 9 & 3.76 & 7 & 3.93 & 4 & 3.69 & 5 & 3.55 & 9 \\
\hline Transportation Diversity & 4.00 & 12 & 3.78 & 6 & 3.76 & 7 & 3.57 & 10 & 3.55 & 11 \\
\hline $\begin{array}{l}\text { Diversity of tourist } \\
\text { accommodation }\end{array}$ & 3.88 & 15 & 3.66 & 12 & 3.82 & 6 & 3.71 & 4 & 4.00 & 2 \\
\hline The quality of the restoration & 4.38 & 5 & 3.63 & 13 & 3.60 & 10 & 3.62 & 8 & 3.45 & 13 \\
\hline $\begin{array}{l}\text { High-tech development } \\
\text { (advanced technology): } \\
\text { robotics festival, video games } \\
\text { room, etc. }\end{array}$ & 3.00 & 21 & 2.93 & 20 & 2.54 & 22 & 2.29 & 22 & 2.18 & 22 \\
\hline $\begin{array}{l}\text { Advertising. promotion of } \\
\text { the tourist destination }\end{array}$ & 3.25 & 19 & 2.80 & 21 & 2.62 & 21.00 & 2.71 & 20 & 2.27 & 21 \\
\hline
\end{tabular}

Source: Authors, processing in the SPSS software

Rho Spearman Rank Order Correlation between: G1\&G2=0.8044- G1\&G3=0.786- G1\&G4=0.7906$\mathbf{G 1 \& G 5}=\mathbf{0 . 6 5 0 4}, \mathrm{G} 2 \& 3=0.857, \mathrm{G} 2 \& 4=0.9002, \mathrm{G} 2 \& \mathrm{G} 5=0.8959, \mathrm{G} 3 \& \mathrm{G} 4=0.9046-\mathrm{G} 3 \& \mathrm{G} 5=0.8738-$ $\mathrm{G} 4 \& \mathrm{G} 5=0.9032$.

Table 14.Ranking variables: Motivation

\begin{tabular}{|c|c|c|c|c|}
\hline What was your motivation for traveling & $\begin{array}{l}\text { Leisure } \\
\text { (G1) }\end{array}$ & ranking & $\begin{array}{l}\text { Business } \\
\text { (G2) }\end{array}$ & ranking \\
\hline Climate (sunny weather, snow and cold. etc.) & 3.59 & 11 & 3.18 & 18 \\
\hline $\begin{array}{l}\text { Architecture and Urban Ambience (Stamp and } \\
\text { Architectural Identity, Cultural Buildings) }\end{array}$ & 3.83 & 5 & 3.33 & 17 \\
\hline Ethnography and folklore (cultural heritage) & 3.53 & 13 & 3.09 & 20 \\
\hline $\begin{array}{l}\text { Professional and event organizations } \\
\text { (conferences and congresses, scientific events, } \\
\text { trade fairs and exhibition fairs, ...etc. }\end{array}$ & 2.40 & 22 & 3.45 & 15 \\
\hline
\end{tabular}




\section{JOURNAL OF TOURISM AND SERVICES}

Issue 20, volume 11, ISSN 1804-5650 (Online)

www.jots.cz

\begin{tabular}{|c|c|c|c|c|}
\hline $\begin{array}{l}\text { Sports facilities and equipment (Olympic Park, } \\
\text { sports competitions, etc.) }\end{array}$ & 2.25 & 23 & 2.58 & 23 \\
\hline Historic Monuments, World Heritage & 3.59 & 12 & 3.48 & 14 \\
\hline Historic Dominance and FAMOUS PEOPLE & 3.44 & 15 & 3.18 & 19 \\
\hline $\begin{array}{l}\text { Public places (Esplanade, walks, botanical } \\
\text { garden, etc.) }\end{array}$ & 3.86 & 4 & 3.55 & 11 \\
\hline $\begin{array}{l}\text { Shopping Resources (galleries and shopping } \\
\text { centers, souvenir shops ...etc.) }\end{array}$ & 3.50 & 14 & 3.64 & 8 \\
\hline Night life & 3.35 & 17 & 3.36 & 16 \\
\hline Security & 4.22 & 1 & 4.27 & 1 \\
\hline $\begin{array}{l}\text { The friendliness and hospitality of the } \\
\text { inhabitants of the host region }\end{array}$ & 3.73 & 8 & 3.79 & 5 \\
\hline Accessibility to health services & 3.36 & 16 & 3.61 & 9 \\
\hline Clean environment & 3.96 & 3 & 4.06 & 2 \\
\hline Quality / Price ratio & 4.07 & 2 & 4.00 & 3 \\
\hline $\begin{array}{l}\text { Assistance services (availability of information, } \\
\text { tourist offices. etc.) }\end{array}$ & 3.34 & 18 & 3.52 & 12 \\
\hline The language spoken in the host destination & 2.90 & 19 & 3.61 & 10 \\
\hline $\begin{array}{l}\text { Transport infrastructure (airport terminal, } \\
\text { seaport. etc.) and easy access to the tourist } \\
\text { destination (Visa, distance) }\end{array}$ & 3.81 & 6 & 3.85 & 4 \\
\hline Transportation Diversity & 3.71 & 9 & 3.73 & 7 \\
\hline Diversity of tourist accommodation & 3.78 & 7 & 3.76 & 6 \\
\hline The quality of the restoration & 3.67 & 10 & 3.52 & 13 \\
\hline $\begin{array}{l}\text { High-tech development (advanced } \\
\text { technology): robotics festival, video games } \\
\text { room, etc. }\end{array}$ & 2.50 & 21 & 2.82 & 22 \\
\hline $\begin{array}{l}\text { Advertising. promotion of the tourist } \\
\text { destination }\end{array}$ & 2.64 & 20 & 2.85 & 21 \\
\hline
\end{tabular}

Source: Authors, processing in the Spss software

Rho Spearman Rank Order Correlation between G1 and G2 $=0.758$

Table 15.Ranking variables: geographical origin

\begin{tabular}{|l|l|l|l|l|l|l|l|l|}
\hline $\begin{array}{l}\text { What is your region of } \\
\text { residence? }\end{array}$ & Africa & $\mathbf{R}$ & Asia - Pacific & $\mathbf{R}$ & America & $\mathbf{R}$ & Europe & $\mathbf{R}$ \\
\hline $\begin{array}{l}\text { Climate (sunny weather, } \\
\text { snow and cold. etc.) }\end{array}$ & 3.5000 & $\mathbf{1 5}$ & 3.6667 & $\mathbf{5}$ & 3.8667 & $\mathbf{1 0}$ & 3.3636 & $\mathbf{1 3}$ \\
\hline
\end{tabular}




\section{JOURNAL OF TOURISM AND SERVICES}

Issue 20, volume 11, ISSN 1804-5650 (Online)

www.jots.cz

\begin{tabular}{|c|c|c|c|c|c|c|c|c|}
\hline $\begin{array}{l}\text { Architecture and Urban } \\
\text { Ambience (Stamp and } \\
\text { Architectural Identity, } \\
\text { Cultural Buildings) }\end{array}$ & 3.7600 & 9 & 3.3333 & 10 & 3.8667 & 11 & 3.7500 & 3 \\
\hline $\begin{array}{l}\text { Ethnography and folklore } \\
\text { (cultural heritage) }\end{array}$ & 3.5000 & 16 & 2.5000 & 20 & 3.6000 & 16 & 3.5227 & 7 \\
\hline $\begin{array}{l}\text { Professional and event } \\
\text { organizations (conferences } \\
\text { and congresses, scientific } \\
\text { events, trade fairs and } \\
\text { exhibition fairs, ...etc. }\end{array}$ & 2.8900 & 21 & 1.9167 & 23 & 2.3333 & 22 & 2.2273 & 20 \\
\hline $\begin{array}{l}\text { Sports facilities and } \\
\text { equipment (Olympic Park, } \\
\text { sports competitions, etc.) }\end{array}$ & 2.4100 & 23 & 2.0000 & 22 & 2.2667 & 23 & 2.2045 & 21 \\
\hline $\begin{array}{l}\text { Historic Monuments, } \\
\text { World Heritage }\end{array}$ & 3.6400 & 12 & 3.0833 & 15 & 3.5333 & 17 & 3.5455 & 6 \\
\hline $\begin{array}{l}\text { Historic Dominance and } \\
\text { FAMOUS PEOPLE }\end{array}$ & 3.3800 & 18 & 3.1667 & 12 & 3.3333 & 18 & 3.5000 & 9 \\
\hline $\begin{array}{l}\text { Public places (Esplanade, } \\
\text { walks, botanical garden, } \\
\text { etc.) }\end{array}$ & 3.9100 & 4 & 3.6667 & 4 & 4.1333 & 7 & 3.4773 & 10 \\
\hline $\begin{array}{l}\text { Shopping Resources } \\
\text { (galleries and shopping } \\
\text { centers, souvenir shops } \\
\text {...etc.) }\end{array}$ & 3.7400 & 10 & 3.0833 & 14 & 3.6667 & 13 & 3.1136 & 16 \\
\hline Night life & 3.5100 & 14 & 3.5000 & 9 & 3.6000 & 14 & 2.8636 & 18 \\
\hline Security & 4.3600 & 1 & 4.0000 & 1 & 4.7333 & 1 & 3.8409 & 1 \\
\hline $\begin{array}{l}\text { The friendliness and } \\
\text { hospitality of the } \\
\text { inhabitants of the host } \\
\text { region }\end{array}$ & 3.7300 & 11 & 3.1667 & 11 & 4.2667 & 5 & 3.7500 & 2 \\
\hline $\begin{array}{l}\text { Accessibility to health } \\
\text { services }\end{array}$ & 3.5500 & 13 & 2.5833 & 19 & 4.2000 & 6 & 3.0455 & 17 \\
\hline Clean environment & 4.1500 & 3 & 3.6667 & 3 & 4.5333 & 2 & 3.5000 & 8 \\
\hline Quality / Price ratio & 4.1800 & 2 & 3.7500 & 2 & 4.4667 & 3 & 3.7045 & 4 \\
\hline $\begin{array}{l}\text { Assistance services } \\
\text { (availability of information, } \\
\text { tourist offices. etc.) }\end{array}$ & 3.4000 & 17 & 3.0833 & 16 & 4.1333 & 8 & 3.1364 & 15 \\
\hline $\begin{array}{l}\text { The language spoken in } \\
\text { the host destination }\end{array}$ & 3.2400 & 19 & 2.4167 & 21 & 3.2667 & 19 & 2.6591 & 19 \\
\hline
\end{tabular}




\section{JOURNAL OF TOURISM AND SERVICES}

Issue 20, volume 11, ISSN 1804-5650 (Online)

www.jots.cz

\begin{tabular}{|l|l|l|l|l|l|l|l|l|}
\hline $\begin{array}{l}\text { Transport infrastructure } \\
\text { (airport terminal, seaport. } \\
\text { etc.) and easy access to the } \\
\text { tourist destination (Visa, } \\
\text { distance) }\end{array}$ & 3.8800 & $\mathbf{7}$ & 3.5000 & $\mathbf{7}$ & 4.3333 & $\mathbf{4}$ & 3.5909 & $\mathbf{5}$ \\
\hline $\begin{array}{l}\text { Transportation Diversity } \\
\text { Diversity of tourist } \\
\text { accommodation }\end{array}$ & 3.8700 & $\mathbf{8}$ & 3.5000 & $\mathbf{8}$ & 3.8000 & $\mathbf{1 2}$ & 3.3864 & $\mathbf{1 2}$ \\
\hline $\begin{array}{l}\text { The quality of the } \\
\text { restoration }\end{array}$ & 3.8900 & $\mathbf{6}$ & 3.5833 & $\mathbf{6}$ & 4.0000 & $\mathbf{9}$ & 3.4773 & $\mathbf{1 1}$ \\
\hline $\begin{array}{l}\text { High-tech development } \\
\text { (advanced technology): } \\
\text { robotics festival, video } \\
\text { games room, etc. }\end{array}$ & 2.8000 & $\mathbf{2 2}$ & 3.1667 & $\mathbf{1 3}$ & 2.3333 & $\mathbf{2 1}$ & 1.9318 & $\mathbf{2 3}$ \\
\hline $\begin{array}{l}\text { Advertising. promotion of } \\
\text { the tourist destination }\end{array}$ & 2.9300 & $\mathbf{2 0}$ & 2.7500 & $\mathbf{1 8}$ & 2.5333 & $\mathbf{1 5}$ & 3.2500 & $\mathbf{1 4}$ \\
\hline
\end{tabular}

Source: Authors, processing in the Spss software 